\title{
Direct evidence of megamammal-carnivore interaction decoded from bone marks in historical fossil collections from the Pampean region
}

Karina Vanesa Chichkoyan ${ }^{1,2}$ Borja Figueirido Corresp., 3 , Margarita Belinchón ${ }^{4}$, José Luis Lanata ${ }^{5}$, Anne Marie Moigne ${ }^{6}$, Bienvenido Martínez Navarro ${ }^{1,7,8}$

1 IPHES, Institut Català de Paleoecologia Humana i Evolució Social, Tarragona, Spain

2 Area de Prehistoria, Universitat Rovira I Virgili (URV), Tarragona, Spain

3 Departmento de Ecología y Geología, Facultad de Ciencias, Universdad de Málaga, Málaga, Spain

${ }^{4}$ Museo de Ciencias Naturales de Valencia, Valencia, Spain

5 IIDYPCa, CONICET, UNRN, San Carlos de Bariloche, Argentina

6 Prehistory Dpt-UMR 7194 HnHp, Musée de l'Homme, Paris, France

7 Area de Prehistoria, Universitat Rovira i Virgili (URV), Tarragona, Spain

8 ICREA, Barcelona, Spain

Corresponding Author: Borja Figueirido

Email address: Borja.figueirido@uma.es

Pleistocene South American megafauna has traditionally attracted the interest of scientists and the popular media alike. However, ecological interactions between the species that inhabited these ecosystems, such as predator-prey relationships or interspecific competition, are poorly known. To this regard, carnivore marks imprinted on the fossil bones of megamammal remains are very useful for deciphering biological activity, and hence, potential interspecific relationships among taxa. In this article, we study historical fossil collections housed in different European and Argentinean museums that were excavated during the $19^{\text {th }}$ and early $20^{\text {th }}$ centuries in the Pampean region, Argentina, in order to detect carnivore marks on bones of megamammals and provide crucial information on the ecological relationships between South American taxa during the Pleistocene. Our results indicate that the long bones of megafauna from the Pampean region (e.g., the Mylodontidae and Toxodontidae families) exhibit carnivore marks. Furthermore, long bones of smaller species and indeterminate bones also present punctures, pits, scores and fractures. Members of the large-carnivore guild, such as ursids, canids and even felids, are recognised as the main agents that inflicted the marks. We hypothesize that the analysed carnivore marks represent the last stages of megaherbivore carcass exploitation, suggesting full consumption of these animals by the same or multiple taxa in a hunting and/or scavenging scenario. Moreover, our observations provide novel insights that help further our understanding of the palaeoecological relationships of these unique communities of megamammals. 
1 DIRECT EVIDENCE OF MEGAMAMMAL-CARNIVORE

2 INTERACTION DECODED FROM BONE MARKS IN HISTORICAL

3 FOSSIL COLLECTIONS FROM THE PAMPEAN REGION

4 Karina Vanesa Chichkoyan ${ }^{1,2}$, Borja Figueirido ${ }^{3^{*}}$, Margarita Belinchón ${ }^{4}$, José Luis Lanata ${ }^{5}$, Anne-Marie

5 Moigne $^{6}$, Bienvenido Martínez-Navarro ${ }^{1,2,7}$

$6{ }^{1}$ IPHES, Institut Català de Paleoecologia Humana i Evolució Social, Tarragona, Spain

$7 \quad{ }^{2}$ Area de Prehistoria, Universitat Rovira i Virgili (URV), Tarragona, Spain

$8{ }^{3}$ Departamento de Ecología y Geología, Facultad de Ciencias, Universidad de Málaga, Málaga, Spain.

$9{ }^{4}$ Museo de Ciencias Naturales de Valencia, Valencia, Spain

105 IIDyPCa, CONICET, UNRN, San Carlos de Bariloche, Argentina.

$11{ }^{6}$ Prehistory Dpt- UMR 7194 HnHp, Musée de l'Homme, Paris, France

$12{ }^{7}$ ICREA, Barcelona, Spain.

13 Corresponding author:

14 Borja Figueirido

15 Departamento de Ecología y Geología, Facultad de Ciencias, Universidad de Málaga, 29071-Málaga, 16 Spain.

17 E-mail: Borja.figueirido@uma.es

18 Tlf: +34655791501

\section{Abstract}


Pleistocene South American megafauna has traditionally attracted the interest of scientists and the popular media alike. However, ecological interactions between the species that inhabited these ecosystems, such as predator-prey relationships or interspecific competition, are poorly known. To this regard, carnivore marks imprinted on the fossil bones of megamammal remains are very useful for deciphering biological activity, and hence, potential interspecific relationships among taxa. In this article, we study historical fossil collections housed in different European and Argentinean museums that were excavated during the $19^{\text {th }}$ and early $20^{\text {th }}$ centuries in the Pampean region, Argentina, in order to detect carnivore marks on bones of megamammals and provide crucial information on the ecological relationships between South American taxa during the Pleistocene. Our results indicate that the long bones of megafauna from the Pampean region (e.g., the Mylodontidae and Toxodontidae families) exhibit carnivore marks. Furthermore, long bones of smaller species and indeterminate bones also present punctures, pits, scores and fractures. Members of the large-carnivore guild, such as ursids, canids and even felids, are recognised as the main agents that inflicted the marks. We hypothesize that the analysed carnivore marks represent the last stages of megaherbivore carcass exploitation, suggesting full consumption of these animals by the same or multiple taxa in a hunting and/or scavenging scenario. Moreover, our observations provide novel insights that help further our understanding of the palaeoecological relationships of these unique communities of megamammals.

\section{Introduction}

Reconstructing the biotic interactions between extinct organisms, including competition or predator-prey relationships, is an extremely difficult task, especially when the information available from living analogues is limited (Figueirido, Martin-Serra \& Janis, 2016). This is particularly true in the case of ancient South American ecosystems, as members of the megafauna became extinct during the latest Pleistocene-early Holocene, and these groups of mammals have no living counterparts (Cione, Tonni \& Soibelzon, 2009; Fariña, Vizcaíno \& de Iuliis, 2013).

Megamammals from the southern portion of South America, or the Pampean (Argentinean) region, have fascinated scientists since the $18^{\text {th }}$ century. Nevertheless, different studies performed to understand their palaeoecology are much more recent (e.g., Fariña, 1996; Bargo, 2003; 
Prevosti, Zurita \& Carlini, 2005; Prevosti \& Vizcaíno, 2006; Figueirido \& Soibelzon, 2010; de los Reyes et al., 2013; Fariña, Vizcaíno \& de Iuliis, 2013; Scanferla et al., 2013; Soibelzon et al., 2014; Bocherens et al., 2016). To this respect, carnivore marks preserved on fossil bones of megaherbivores constitute an important source of information, as they represent direct evidence of predator-prey relationships, or alternatively, of scavenging activity by top predators such as strictly flesh-eating or bone-cracking hypercarnivores, respectively (e.g., Haynes, 1982; Marean \& Ehrhardt, 1995; Pobiner \& Blumenschine, 2003; Pickering et al., 2004; Palmqvist et al., 2011; Espigares et al., 2013). Consequently, detecting the marks of biological activity preserved on the bone surfaces of Pampean megamammals, using detailed taphonomic investigations and nextgeneration techniques, is crucial for deciphering the ecological relationships between Pleistocene South American palaeocommunities.

Previous studies of bone surfaces performed on fossil collections housed in various museums in the Americas have revealed carnivore activity, and hence animal interaction (Haynes, 1980; Martin, 2008, 2016; de Araújo Júnior, de Oliveira Porpino \& Paglarelli Bergqvist, 2011; Dominato et al., 2011; Labarca et al., 2014). Indeed, in South America, carnivore marks have been reported from different locations (Fig. 1). Specifically in the Pampean region, there is a neural apophysis of a glyptodont cf. Eosclerocalyptus lineatus (Glyptodontidae, Hoplophorini) from the Pliocene (Olavarría) with a clear carnivore tooth imprint, attributed to a giant Chapalmalania (Carnivora, Procyonidae) procyonid (de los Reyes et al., 2013). Recently, a taphocoenosis from the margins of the Salado River, comprising remains of the equid Hippidion principale (Perissodactyla, Equidae) and some indeterminate bones with carnivore marks was associated with the dirk-toothed sabre cat Smilodon sp. (Carnivora, Felidae, Machairodontinae) (Scanferla et al., 2013). At the archaeological site Arroyo Seco 2, bones of extinct horses such as Equus sp. (Perissodactyla, Equidae) show carnivore marks (Politis et al., 2016). In Patagonia, the jaguar Panthera onca mesembrina (Carnivora, Felidae, Pantherinae) was reportedly responsible for interventions involving the ground sloth Mylodontidae (Xenarthra, Tardigrada) and Hippidion groups (Martin, 2008, 2016), and a member of Felidae produced marks on mastodont (Mammalia, Proboscidea; Gomphotheriidae) bones (Labarca et al., 2014) during the late Pleistocene. In Brazil, two sites have been described where the small canid Protocyon troglodytes (Carnivora, Canidae) presumably scavenged the carcasses of two mastodons, Notiomastodon platensis (Proboscidea, Gomphotheriidae), the giant ground sloths Eremotherium laurillardi (Tardigrada, Megatheriidae) and Glossotherium (Tardigrada, Mylodontidae) (de Araújo Júnior, de 
80 Oliveira Porpino \& Paglarelli Bergqvist, 2011), and Haplomastodon waringi (Mammalia,

81 Proboscidea) in the Pleistocene (Dominato et al., 2011).

82 In this article, we study for the first time, carnivore marks on megamammal ( $>1000 \mathrm{~kg}$; Cione,

83 Tonni \& Soibelzon, 2009) remains from different fossil collections recovered from the Pampean

84 region and now housed in various institutions in Europe and Argentina. Our goal is to identify

85 potential biological activity using taphonomic methods in order to understand predator-

86 megaherbivore interaction within Pleistocene South American mammalian communities from the

87 Pampean region.

\section{Materials \& Methods}

89 In order to identify those bones showing evidence of carnivore intervention, we examined 1,976 bones belonging to the following four collections (Table 1): (i) 1,478 bones from the Rodrigo Botet collection, housed at the Museo de Ciencias Naturales de Valencia (MCNV; Spain), result of the excavations undertaken by Enrique de Carles in the northeast of the Buenos Aires province (Belinchón et al., 2009); (ii) 30 bones from the Dupotet collection, housed at the Muséum National d' Histoire Naturelle (MNHN; Paris, France) of Pampean age from Luján City; (iii) 330 bones from the Krncsek collection, housed at the Naturhistorisches Museum Wien (NMW; Austria) that proceed from the Luján River in Mercedes City, and are identified as "DiluviumUpper Pampean"; and (iv) 138 bones from the Canal de Conjunción collection (La Plata), housed at the Museo de La Plata (MLP), and which were extracted from a $20 \mathrm{~m}$ stretch along both sides of a water channel (Ameghino, [1889] 1916:128-129).

These collections were gathered during various non-systematic excavations carried out in the eastern region of what is currently Buenos Aires province, in the Pampean region (Argentina), during the $19^{\text {th }}$ and early $20^{\text {th }}$ centuries. This is an extensive, flat geomorphological unit located in the central area of Argentina. The Quaternary was characterised by loess deposition, with different regressive and transgressive events (Fucks \& Deschamps, 2008; Cione, Tonni \& Soibelzon, 2009). The early and middle Pleistocene corresponds to the Ensenadan and Bonaerian Stages/Ages that were characterised by a cold and arid environment (Fucks \& Deschamps, 2008; Cione, Tonni \& Soibelzon, 2009). An important faunal turnover marks the boundary between the two stages, at ca. 0.5 Ma (Cione, Tonni \& Soibelzon, 2009). The late Pleistocene-early Holocene corresponds to the Lujanian Stage/Age. Significant palaeoenvironmental oscillations, aeolian 
110 pulses, fluvial process and various pedogenetic events influenced this period (Tonni et al., 2003;

111 Fucks \& Deschamps, 2008; Cione, Tonni \& Soibelzon, 2009). When the collections analysed in

112 this study were originally collected, these units were included in the "Pampean Formation"

113 (Tonni, 2011). Current biostratigraphical information (Tonni, 2009) allows the material from

114 MCNV to be assigned to the Ensenadan to Lujanian, Stage/Age and the material from MNHN

115 and NMW to the Bonaerian and Lujanian Stages/Ages. Furthermore, in the NMW collection, the

116 old reference to Upper Pampean is currently equivalent to the Bonarian Stage/Age (Tonni, 2011).

117 The last record of these mammal groups comes from the Guerrero Member of the Luján

118 Formation, deposited between 21,000 and 10,000 ${ }^{14} \mathrm{C}$ years BP. (Tonni, 2009). In the case of the

119 MLP assemblage, the presence of the notoungulate Mesotherium cristatum (Notoungulata,

120 Mesotheriidae) among the identified species means this material can be dated as Ensenadan

121 (Cione, Tonni \& Soibelzon, 2009) (Fig. 2 and Table 1).

122 To understand the natural burial conditions of the remains, we considered different types of bone 123 surface modifications such as post-depositional fractures, the presence of original sediment or 124 concretions, fluvial erosion, trampling, weathering, root growth, manganese spots and burning 125 traces (e.g., Behrensmeyer, 1978; Binford, 1981; Shipman, 1981; Olsen \& Shipman, 1988; 126 Lyman, 1994; Fernández-Jalvo \& Andrews, 2003, 2016). These allowed us to discard any type of 127 intervention that could simulate carnivore activity or, if superimposed onto carnivore marks, 128 could have indicated a previous carnivore intervention.

We follow the literature to identify whether bone marks were the result of carnivore activity (e.g., Haynes, 1980, 1982, 1983; Binford, 1981; Capaldo \& Blumenschine, 1994; Lyman, 1994; Domínguez-Rodrigo \& Piqueras, 2003; Pickering et al., 2004; Domínguez-Rodrigo et al., 2012; Delaney-Rivera et al., 2009; Sala, Arsuaga \& Haynes, 2014; Sala \& Arsuaga, 2016). As large mammal bones are too large to be ingested (Fernández-Jalvo \& Andrews, 2016), we did not considered this effect as a possible agent of the marks. Furthermore, small bones tend to be splintered by the teeth of predators, making them impossible to classify either anatomically or taxonomically (Fernández-Jalvo \& Andrews, 2016). Therefore, this type of fragmented material was not included in our review. The only exception was the case of the indeterminate and smaller bones from the MLP collection where part of the original association was conserved. Coprolites were absent in the reviewed collections.

140 We classified the bone marks potentially produced by carnivores into four categories (Table S1): 141 (i) pitting and/or punctures, (ii) u-shaped elongated scratches or scores, (iii) furrowing; and (iv) 
142 spiral fractures. To investigate the body size of the potential carnivores that inflicted the marks,

143 we used a box-plot diagram (Hammer, Harper \& Ryan, 2001) to compare the size of the pitting

144 and/or punctures from the MCNV, MNHN and MLP specimens with those published by

145 Pickering et al. (2004) (various bones), de los Reyes et al. (2013) (bone specimen Xen 30-12),

146 and Martin (2016) (various bones); the material from NMW was excluded for the small sample

147 size (Table S2 to S5). We follow the studies mentioned above as they allowed us to compare

148 palaeontological and archaeological cases from the Pampean region, Patagonia, and one African

149 case, and appreciate any similarities and/or differences with African ecosystems. Even though

150 this information was still statistically poor, it allowed us to make some preliminary assumptions.

151 Additionally, assigning a pit or puncture to a specific taxa is always problematic given the

152 different factors involved (e.g., the part of the bone marked and the bite force of an animal)

153 (Delaney-Rivera et al., 2009). Nevertheless, the overlapping of our data with the comparative

154 cases allowed us to ascribe the marked bones to general carnivore size categories. Even though

155 some authors have also included scores in their studies of body size (Delaney-Rivera et al., 2009;

156 Labarca et al., 2013, de Araújo Júnior, de Oliveira Porpino \& Paglarelli Bergqvist, 2011), we

157 agree with Domínguez-Rodrigo \& Piqueras (2003) that score marks relate not only with teeth

158 size, but also the effect of the teeth being dragged over the bone surface; variability can therefore

159 be expected from this type of marks.

160 We also reviewed actualistic studies describing the marks that different carnivore taxa leave when

161 feeding and, more specifically, recent research into marks made by the members of the large

162 carnivore guild, such as ursids (Carnivora, Ursidae), felids (Carnivora, Felidae) and canids

163 (Carnivora, Canidae) (Table S1). Specialised bone-breaking hyenas were not considered because

164 they were not present in South America at that time. Various studies report that ursids leave

165 scarce to abundant teeth marks (Haynes, 1980, 1983; Burke, 2013; Saladié et al., 2013; Arilla et

166 al., 2014; Sala \& Arsuaga, 2016). In contrast, felids tend to make fewer marks on the bones since

167 they feed exclusively on meat (Christiansen \& Wroe, 2007; Sala \& Arsuaga, 2016), although they

168 can leave important signs of predation (Haynes, 1983; Marean \& Ehrhardt, 1995; Martin 2008,

169 2016; Domínguez-Rodrigo et al., 2012; Kaufmann et al., 2016; Sala \& Arsuaga, 2016). Finally,

170 canids can make a great number of intervention marks (Haynes, 1982, 1983; Yravedra et al.,

171 2011; Burke, 2013; Domínguez-Rodrigo et al., 2012; Sala, Arsuaga \& Haynes, 2014; Sala and

172 Arsuaga 2016). Furthermore, while felids (including Smilodon) and ursids have straighter incisive

173 arcades, canids have curved arcades (Biknevicius, Van Valkenburgh \& Walker, 1996). This shape 
174 is useful when analysing pitting and/or puncture arrangements on bone surfaces (e.g., linear or

175 curved rows of tooth impressions).

176 We examined the fossil remains of the megaherbivores present in the collections with 3.5x and

177 12x magnifying glasses. We also used a Dino-Lite Microscope AD4113T (at magnifications of

$17820 \mathrm{x}$ to $45 \mathrm{x}$ ) and the software Dino-Lite 2.0. Both the length and breadth (major and minor axes)

179 of the scores, pits and punctures were measured. Larger marks were measured using a caliper,

180 and smaller ones were recorded with the measurement tool installed in the Dino-Lite. For each

181 collection, high-resolution digital images were taken, in each museum, using a Panasonic Lumix

182 DMC-TZ35 camera.

183 For the MLP assemblage we also applied the well-established archaeozoological variables MNI

184 (Minimum Number of Individuals) and NISP (Number of Identified Specimens), as all the

185 specimens are part of the same taphocoenosis (Lyman, 1994). While MNI was used to account

186 for the minimum number of mammals with carnivore marks represented in the sample, the

187 second informed the counting per taxa or skeletal part categories.

\section{Results}

189 We found four bones $(0.2 \%$ of the total) of megaherbivores and 24 bones $(1.24 \%$ of the total) of

190 smaller and indeterminate species with potential carnivore intervention. In addition, a detailed

191 description of the marks is given in the supplementary information (Data S1). Below, we give a

192 general overview of the most important damage found in each collection (Table 2 and Table S5)

193 and provide general observations from the box-plot diagram (Fig. 3):

194 (i) A right tibia from the MCNV (n 64-492) that corresponds to the ground sloth cf.

195 Scelidotheriinae gen (Tardigrada, Mylodontidae). This bone presents important furrowing on both

196 epiphyses and pits and scores on the distal epiphysis, as well as on the posterior and medial faces

197 of the diaphysis (Fig. 4). In the box plot diagram it can be observed that the measurements of

198 these pits slightly overlaps with the maximum sizes of large carnivores (and outliers) from

199 Pickering et al. (2004) and falls within the measurements presented by de los Reyes et al. (2013),

200 but are slightly bigger than the Pampean case (de los Reyes et al., 2013). Nevertheless, this

201 discrepancy could be due the bigger pit from MCNV that seems to be enlarged by post-

202 depositional process (Data S1 and Fig. S1). They also coincide with the smaller sizes from Cueva

203 del Milodón (Martin, 2016); 
204 (ii) A left humerus of Glossotherium robustum labelled MNHN.F. PAM 119 from MNHN, with 205 pits, scores and furrowing (Fig. 5). Comparing this with the other samples reveals the same trend 206 as for MCNV. It matches with the log area of the tibia from MCNV, but also overlaps more with 207 the specimens in Pickering et al. (2004) because of the presence of smaller pits on the MNHN 208 bone. It also coincides with the range of Xen 30-12, but has bigger and smaller log area extremes 209 than the Pampean case (de los Reyes et al., 2013). In addition, it compares well with the smaller 210 marks from Cueva del Milodón (Martin, 2016);

211 (iii) A left distal humerus of Mylodon robustum ( $\mathrm{n}^{\circ}$ 1908.XI.110) housed at MNW with furrowing 212 and a possible puncture (Fig. 6). The furrowed border is scalloped and part of it is flaked. This 213 species is considered to represent Glossotherium robustum (McAfee, 2009). Although not plotted, 214 Table S5 shows that the log area coincides with the range for the rest of the sampled material; and 215 (iv) At the MLP, one femur condyle from the notoungulate Toxodontidae (MLP 15-I-20-32) 216 (Notoungulata; Toxodonta) was found with scratches (Fig. 7). Moreover, in this collection 22 217 long bones of smaller species and two further indeterminate bones have fresh fractures, scratches, 218 punctures/pits and crenulated edges (details of these marks are shown in Table S6) (Fig. 8 to 10). 219 The box plot reveals the same trend for these pits and punctures as seen in the other cases.

220 Nevertheless, the presence of smaller marks on this sample results in greater coincidence with the 221 Swartkrans specimens (Pickering et al., 2004), and there is partial overlap with Xen 30-12 (de los 222 Reyes et al., 2013). However, only the outliers from MLP coincide with the smaller sizes from 223 Cueva del Milodón (Martin, 2016), and the plot partially overlaps with those of the material from $224 \mathrm{MCNV}$ and MNHN. The smaller pits on the MLP specimens were considered together with the 225 bigger punctures on the two indeterminate bones. Large carnivores can generate both small and 226 large pits and/or punctures (Delaney-Rivera et al., 2009), and this may explain the variability in 227 the marks observed here.

\section{Discussion}

229 The information presented above suggests that the different types of bone marks found on both 230 megamammal and small mammal remains were most likely inflicted by some large-sized 231 carnivores that inhabited the Pampean region during the Pleistocene. Considering the limited 232 evidence available from this region, the data presented here is crucial for exploring different 233 predator-prey and/or scavenging scenarios, at a coarse scale. 
234

235

236

237

238

239

240

241

242

243

244

245

246

247

248

249

250

251

252

253

254

255

256

257

258

259

260

261

262

263

264

The agents: Pleistocene mammalian predators from the Pampean region

Several species of Quaternary carnivores have been recorded from the Pampean region. In the supplementary information, we offer a general description of these, along with some ecological characteristics (Data S2). These carnivores include ursids, felids and canids. The ursids comprise Arctotherium angustidens from the Ensenadan Stage/Age and Arctotherium vetustum, Arctotherium bonariense and Arctotherium tarijense from Bonarian and Early Lujanian times (Soibelzon et al., 2014; Figueirido \& Soibelzon, 2010). In particular, the first species would have had an important capacity to feed on meat (Figueirido \& Soibelzon, 2010). Felids are represented by three hypercarnivorous species: Smilodon populator, Puma concolor and Panthera onca (Christiansen \& Harris, 2006; Prevosti \& Vizcaíno, 2006; Bocherens et al., 2016). While the first two had some bone marking capacity, the third would have been capable of inflicting more damage (Van Valkeburgh \& Hertel, 1993; Marean \& Ehrhardt, 1995; Antón et al., 2004; Martin, 2008, 2016; Muñoz et al., 2008; Binder \& Van Valkenburgh, 2010; Domínguez-Rodrigo et al., 2015; Kaufmann et al., 2016). Finally, several pack-hunting and/or scavenging canids were present at the time, including Theriodictis platensis (and its sister taxon " $C$ ". gezi) in the Ensenadan (Prevosti \& Palmqvist, 2001; Prevosti, Tonni \& Bidegain, 2009), various Protocyon species throughout the Pleistocene (Prevosti, Zurita \& Carlini, 2005; Prevosti \& Schubert, 2013; Bocherens et al., 2016), Canis nehringui (currently recognised as a junior synonym of C. dirus, Prevosti, Tonni \& Bidegain, 2009), and Dusicyon avus in the Late Pleistocene (Prevosti \& Vizcaíno, 2006).

It is clear that carnivores with an important capacity for bone modification and/or consumption would have been responsible for the various marks observed. Even though felids such as Smilodon or Puma could have produced some bone-damage, as observed in some studies (Van Valkeburgh \& Hertel, 1993; Marean \& Ehrhardt, 1995; Muñoz et al., 2008; Kaufmann et al., 2016), their reduced bone-breaking potential rules them out as the principal generator of the feeding traces recorded. Furthermore, it is worth mentioning that the highly specialised visceraeating dentition of the dirk-toothed Smilodon would have prevented this animal from feeding on carrion unlike other scimitar-toothed predators (e.g., Homotherium) (Palmqvist et al., 2007).

\section{Identifying potential agents of the megamammal tooth-marks}

Based on the box plot comparisons (Fig. 3), the marks on the samples in this study best match those made by the giant Pampean Chapalmalania (de los Reyes et al., 2013). This procyon had 
265 previously been compared with a bear, although according to de los Reyes et al. (2013) the 266 cranial configuration is more similar to that of hyenas. From the information presented by

267 Pickering et al. (2004), it seems that the damage inflicted also coincides to some degree with that 268 made by large African carnivores, such as large canids, spotted hyenas and lions, or the smaller 269 marks realised by Panthera onca mesembrina (Martin, 2016). These African species correspond 270 to sizes 2 or 3 in the Bunn ranking (1986). Cross-referencing these sizes with the Pampean 271 carnivores, they coincide with several ursids, felids and canids, although some Pampean species 272 were larger, such as Smilodon populator, size 4, and Arctotherium angustidens, size 5 (Table 3). 273 Moreover, the reports from the various South American sites involving pitting and/or punctures 274 show a similar range of values as seen in this study (Table 4). Most of this information could not 275 be plotted, as the number of marks found at each site was too low to be able to input them into 276 the calculation. Nevertheless, it can be observed that the majority range from 5 to $10 \mathrm{~mm}$ in size 277 (those from Cueva del Milodón are larger, as shown in the box-plot). According to this data, 278 different members of the Pampean large-carnivore guild would have produced the bone damage 279 observed on the samples from the various museums. To determine which carnivores were 280 involved, we must relate the marks to the types of bone damage generated by the potential ursid, 281 felid and canid taxa.

282 The MCNV cf. Scelidotheriinae gen. tibia is the bone that presents the most significant carnivore 283 interventions. A combination of pitting, scratches and important furrowing was observed, on both 284 the epiphyses and medial faces. Even though all three groups of carnivores were capable of 285 leaving these types of marks, certain characteristics allow us to relate this damage to ursids. In 286 particular, the group of aligned pits imprinted on the medial rim (Fig. 4A) of the distal epiphysis 287 is planar that could indeed have been made by the premolars or molars of ursids (Haynes, 1983). 288 In contrast, the parallel, V-shaped tooth marks on the posterior face (Fig. 4C and Fig. 4E) could 289 be related to a series of incisors and canines and would coincide with the dragging action of a straight incisor arcade (Biknevicius, Van Valkenburgh \& Walker, 1996). On the other side, the parallel scores, like those seen on the distal metadiaphysis (Fig. 4B), are also generally characteristic of ursids (Haynes, 1983; Saladié et al., 2013). In addition, the intensive furrowing coincides with the bone-breaking capacity of this animal (Soibelzon et al., 2014). Other damage typical of ursids observed on the tibia includes the elongated gouge on the lateral side of the articular face (Fig. 4A) and the quadrangular-shaped grooves on the medial face of the diaphysis (Fig. 4D) (Burke, 2013; Saladié et al., 2013). That being said, these grooves, and the gouges 
297 observed on the distal metadiaphysis, do not have the regular walls and bottoms characteristic of 298 ursid marks (Saladié et al., 2013). Also, according to current research, this damage should be 299 superficial, a feature not observed on this bone (Haynes, 1983; Saladié et al., 2013). To this 300 respect, some authors suggest that the damage produced by ursids is less intense than that 301 inflicted by other groups (Haynes, 1983; Arilla et al., 2014; Sala \& Arsuaga, 2016), a pattern not 302 observed here. Consequently, more than one animal may have participated in imprinting the 303 complex and producing the marks observed on this tibia. If that is the case, Panthera onca could 304 have been involved, too. This species also possessed straight incisive arcades (Biknevicius, Van 305 Valkenburgh \& Walker, 1996) that could have produced the elongated V-shape marks (Haynes, 306 1983) on the posterior face. The important furrowing noticed at both ends of the bone is also consistent with this felid's damage-producing capacity (Martin, 2008, 2016; Domínguez-Rodrigo et al., 2015).

309 The humerus of Glossotherium robustum housed in the MNHN has suffered less bone loss than the tibia. Feeding marks on this element have several characteristics that could indicate its consumption by Arctotherium. As observed on the tibia, the short, wide scratches present on the condyle and the wide, elongated, superficial pitting, agree with actualistic studies of ursid marks (Fig. 5B and Fig. 5C) (Haynes, 1983; Burke, 2013; Saladié et al., 2013). Nevertheless, the presence of V-shape punctures in the trochlea (Fig. 5B), characteristic of felids rather than ursids, means that other taxa, such as Panthera onca, cannot be ruled out (Haynes, 1983). Both groups were capable of furrowing the epiphysis (Martin, 2008; Arilla et al., 2014; Domínguez-Rodrigo et al., 2015) as observed on the trocheal part of the bone (Fig. 5D).

318 The furrowing on the MNW Glossotherium robustum humerus is more ambiguous than the marks 319 on the other two bones, since various taxa could have inflicted this type of damage on cancellous bone (Fig. 6A to 6D). The cusp that made the puncture could have been on a secodont tooth from a felid or canid (Fig. 6B). Both these groups have the capacity to damage and destroy cancellous tissue, although canids leave fewer marks on mammals larger than $400 \mathrm{~kg}$ (Yravedra, Lagos \& Bárcena, 2011). Patagonian sites with important furrowing in Mylodontidae bones, attributed to Panthera onca mesembrina, could provide an important parallel (Martin, 2008, 2016) when considering the types of marks that jaguars can make on limb bones, as seen in this case. The marked femur of Toxodontidae from the MLP must be integrated with the other evidence from the taphocoenosis in order to interpret which carnivore species was involved. Of the 138 bones studied from this site, $61.59 \%$ (NISP: 85) belong to indeterminate species, while the remaining $38.40 \%$ (NISP: 53) were identified to genus level. Among these, equids are the most 
330

331

332

333

334

335

336

337

338

339

340

341

342

343

344

345

346

347

348

349

350

351

352

353

354

355

356

357

358

359

360

361

common, accounting for $36.53 \%$ (NISP: 19) of the identified elements. Megamammal bones are the second most widely represented group, with $30.76 \%$ (NISP: 16). The assemblage predominantly comprises appendicular skeletal elements (73.92\% or NISP: 102). Axial and planar bones contribute only $13.77 \%$ (NISP: 19) and indeterminate fragments account for $12.31 \%$ (NISP: 17). Of the carnivore-marked bones, 88\% (NISP: 22) are indeterminate diaphysis of the long bones mentioned above (Tab. S6), coinciding with the general abundance of limb elements. Carnivore-marked bones represent only $18.11 \%$ (NISP: 25 ) of the total assemblage. The low proportion found at this site could have been influenced by its location in running water. As explained by Ameghino, ([1889] 1916) the material from this site was scattered along a $20 \mathrm{~m}$ stretch on both sides of a channel. Therefore, the current may not only have dispersed the primary association, but also mixed it with bony remains not originally consumed by the carnivore/s involved. This may also have influenced the skeletal assemblage, including the paucity of axial parts, resulting from density-mediated destruction or the winnowing of lighter axial bones.

Nevertheless, the fact that carnivores mark $18.11 \%$ of the bones also indicates that a basic level of primary association remained when this material was collected. The presence of the Toxodontidae femur and other smaller bones with carnivore marks indicates that a MNI of 2 animals were consumed in the location itself. In addition, the dominance of fractured long bones could, partly, have been the result of carnivore activities that transported limbs to this area. Consequently, the carnivore/s involved in the formation of the collected assemblage must have had the capacity to break long bones and/or the ability to predate upon megamammals. In this sense, given the absence of specialised bone-crushers in the Americas, some type of canid may have been responsible for the described interventions. It is likely that either Theriodictis platensis or Protocyon scagliorum from the Ensenadan Stage/Age generated these marks, as also inferred for the Brazilian cases (de Araújo Júnior, de Oliveira Porpino \& Paglarelli Bergqvist, 2011; Dominato et al., 2011).

In any event, although the proportion of carnivore marks that we have found on bones of megamammals is relatively low, this precludes the conclusion that the sites where the remains were originally collected represented the den of a hypercarnivore or bone-cracking species. Other potential carnivores specialising in medium-sized and/or small taxa, such as Canis nehringui or Dusicyon avus, could have fed on the megaherbivore community during the late Pleistocene (Prevosti \& Vizcaíno, 2006; Prevosti, Tonni \& Bidegain, 2009). At ca. 14.000 cal yrs BP (Politis et al., 2016) Homo sapiens also became part of the carnivore guild. Humans not only 
362 scavenged megamammal carcasses (Politis et al., 2016), but were also more successful hunters of

363 these animals than the existing carnivores (Cione, Tonni \& Soibelzon, 2009).

364 Megamammal carcass consumption during the Pleistocene

365 Considering the skeletal elements, bone mark locations, and the level of use of the bones, it

366 seems most likely that these marks represent the final stages of megamammal carcass

367 consumption.

368 (i) Marks on the tibia and the humeri are situated on the epiphysis, both the articular surface and 369 metadiaphyses. In a hunting event, carnivores that have access to a large mammal usually begin

370 to feed on the abdominal part, later moving to femoral muscle masses, leaving some marks on the 371 distal epiphyses and diaphyses (Haynes \& Klimowicz, 2015). Forelimbs are usually consumed

372 later, since the skin is harder in these areas (Haynes, 1982; Haynes \& Klimowicz, 2015). The

373 same usually happens with lower limb bones, such as the tibia, due to their smaller quantities of 374 meat (Haynes, 1982; Blumenschine, 1986; Haynes \& Klimowicz, 2015). The intense gnawing of 375 the cf. Scelidotheriinae gen. tibia, both on the distal epiphysis and medial face of the diaphysis, as 376 well as, to a lesser degree, on the proximal epiphysis, implies that this element was fully

377 exploited. The presence of marks on the diaphysis indicates that even the hardest part of the shaft 378 was utilised. The same is true for both Glossotherium robustum humeri. The damage to the distal 379 epiphyses was inflicted in subsequent stages and not at the beginning of the consumption 380 sequence. The presence of furrowing on the three elements implies that the various carnivores involved were consuming a substantial amount of bone. In the case of the MLP assemblage, the dominance of broken long bone diaphyses indicates access to within-bone nutrients, relating to the last stages in the consumption sequence (Binford, 1981; Haynes, 1982; Blumenschine, 1987;

384 Capaldo \& Blumenschine, 1994).

385 (ii) Intensity of carcass use is related to resource availability (Haynes, 1980, 1982; Van 386 Valkeburgh \& Hertel, 1993; Delaney-Rivera et al., 2009), the size of the hunting pack (Van 387 Valkenburgh et al., 2016), or multiple carnivore taxa involvement (Pobiner \& Blumenschine, 2003; Delaney-Rivera et al., 2009). In general terms, large animal tissue is usually conserved for longer once dead (Blumenschine, 1987) and their bones have fewer marks than seen on bones of smaller species (Yravedra, Lagos \& Bárcena, 2011; Domínguez-Rodrigo et al., 2015). As the easy-to-access meat is consumed, carnivores tend to eat the remaining parts of the carcass and inflict more significant damage to the bones (Binford, 1981; Haynes, 1982; Blumenschine, 1986; 
393 Pobiner \& Blumenschine, 2003; White \& Driedrich, 2012; Haynes \& Klimowicz, 2015, Sala \& 394 Arsuaga, 2016). Thus, marks on articulation surfaces could indicate that the bone held only a 395 small amount of meat when the intervention took place. This is the case of the cf.

396 Scelidotheriinae gen. tibia from the MCNV, the Glossotherium robustum left humerus from the 397 MNHN, and the Toxodontidae femur from the MLP (along with other broken bones). The same 398 hypothesis can be proposed for the Glossotherium robustum humerus from the MNW, although in 399 this case, a lack of marks on the articulation surface could indicate that the bone was still attached 400 to the rest of the limb. In general, the intensity of the marks and fractures observed indicates 401 advanced stages of modification (Haynes, 1982; Sala \& Arsuaga, 2016).

402 The described feeding traces therefore appear to indicate that during the Pleistocene, different 403 species within the large carnivore guild would have accessed and consumed megamammal bones 404 and/or the marrow of smaller animals, in the final stages of a consumption sequence. Although 405 discussion of how the animals were predated is difficult without more contextual information, 406 given the multiple possibilities for carnivore exploitation of megamammal carcases (Pobiner \& 407 Blumenschine, 2003), two possible extreme scenarios are considered here: the marks described 408 resulted from a first access (hunting) event and/or secondary access (scavenging) activity. The 409 first case would involve the same group of carnivores killing and consuming the edible muscle 410 tissues and then exploiting bones and within-bone nutrients. Early access to the carcass of an 411 animal that had died a natural death by the same carnivore group can be also included in this 412 situation (Blumenschine, 1986). Alternatively, after the death of the animal (either from natural 413 causes or hunting activities), various carnivore taxa could have fed on a single carcass. In this 414 second situation, one group would have consumed the primary edible tissues of the bony 415 elements, and, at a later stage, the bones and marrow would have been exploited by other 416 carnivores.

417 These interventions resulting from hunting and/or scavenging events indicate that in both cases, megamammal carcasses were completely exploited by various members of the large-sized carnivore guild in the region. Our samples belong to different time periods within the Pleistocene

420 (Fig. 2 and Table 1). This provides weak but positive evidence suggesting that consumption of 421 edible tissues as well as the bony elements and/or marrow by different carnivore groups was a pattern that occurred repeatedly throughout that period. Full exploitation of carcasses is expected, at least periodically when food is scarce and/or more carnivore species are present, as has been 424 proposed for other American ecosystems such as Rancho La Brea (Van Valkeburgh \& Hertel, 
425 1993; Binder \& Van Valkenburgh, 2010; Van Valkenburgh et al., 2016). Thus, it seems likely that

426 temporal palaeoenvironmental stressors would have influenced the richness of Pampean

427 megamammal communities (Cione, Tonni \& Soibelzon, 2009), acting as cyclic, top-down

428 pressures stimulating interspecific and intraspecific competition for the carcasses, resulting in the

429 complete consumption of them.

\section{Conclusions}

431 Four megaherbivore fossil bones, 22 bones of smaller species, and two indeterminate bones with

432 carnivore marks were studied from European and Argentinean collections of Pleistocene remains

433 from the Pampean region, collected during the $19^{\text {th }}$ and early $20^{\text {th }}$ centuries. The marks were

434 predominately identified on appendicular bones. After internal organs and muscles are consumed,

435 limb bones are the richest parts with regard to within-bone nutrients, and in particular, the

436 epiphyses are the easiest to penetrate by gnawing (Binford, 1981; Dominato et al., 2011; Labarca

437 et al. 2014). Analysis of the punctures and pitting shows that these partially overlap with the

438 range of bigger marks made by large carnivores from African environments, the smaller markings

439 of Panthera onca mesembrina, and they are comparable with the giant Chapalmalania from the

440 Pliocene of the Pampean region (Pickering et al., 2004; de los Reyes et al., 2013; Martin, 2016).

441 Moreover, our measurements generally agree with the information reported from other South

442 American sites (Martin, 2008; Dominato el al. 2011; Labarca et al., 2014; Politis et al., 2016).

443 Consequently, it is likely that different members of the Pampean large-carnivore guild produced

444 the marks described in this study. We interpret the data presented here as indicating the fact that

445 ursids, canids, and possibly felids would have consumed the soft and hard tissues, inflicting

446 various tooth marks, including pits, punctures, and scratches, furrowing bone epiphyses, and even

447 breaking the diaphyses of long bones in order to access the marrow. These latter represent the

448 final stages of carcass exploitation, given that the marks described on the epiphyses and

449 diaphyses were not inflicted when bone still held large quantities of meat.

450 Considering that there is little information on carnivore marks from the region, as this type of

451 evidence is still scarce, the few remains presented here significantly increase our knowledge of

452 palaeoecological relationships in the Pampean region. The marked bones indicate that the

453 megamammal carcases were fully exploited. This type of evidence has been recorded in the

454 Pliocene (de los Reyes et al., 2013) and, according to the evidence presented here, continued 
455 periodically throughout the Pleistocene. Consequently, temporal shifts in prey availability would

456 have influenced predator-prey and/or scavenging dynamics, increasing competition for carcasses

457 and resulting in the consumption of bone and within-bone nutrients by the same or multiple taxa.

458 Pleistocene large mammal communities would have developed different trophic levels with

459 multiple competitive species, allowing them to persist through time and overcome different

460 palaeoclimatic fluctuations. This situation lasted until the late Pleistocene-early Holocene when

461 many megafaunal extinctions occurred (Van Valkenburgh et al., 2016).

462 Current taphonomic methods allow new results to be obtained from historical collections. In this

463 study, different types of carnivore marks inflicted on megamammal and smaller mammal bones

464 were measured and categorised. Interpreting these with the help of current ecological information

465 sheds light onto the palaeoecological relationships of native Pampean mammal communities from

466 the Pleistocene. This novel perspective offers new insights into the development of future

467 systematic fieldwork. Both collection- and field-based research will provide crucial information

468 on the evolution of the Pleistocene ecosystems of the South American Southern Cone.

\section{Acknowledgments}

470 We thank Christine Argot and Guillaume Billet (MNHN), Ursula Göhlich (NMW), and Marcelo

471 Reguero and Martín de los Reyes (MLP) for allowing access to the collections under their care.

472 KVCH thanks Noel Amano from IPHES who helped with the PAST program and development of

473 the graphics. We are especially grateful to Sam Arman, Briana Pobiner and an anonymous

474 reviewer, whose comments, suggestions and critiques have improved this manuscript and given

475 new insights into several ideas. 
476

\section{REFERENCES}

477 Ameghino F. [1889] 1916. Los mamíferos fósiles de la República Argentina, Parte 1

478 Planungulados y Ungulados. In: Torcelli AJ, ed. Obras completas y correspondencia científica de 479 Florentino Ameghino. La Plata: Taller de Impresiones Oficiales, Vol VI.

Antón M, Salesa MJ, Pastor JF, Sánchez IM, Fraile S, Morales J. 2004. Implications of the mastoid anatomy of larger extant felids for the evolution and predatory behavior of sabre toothed cats (Mammalia, Carnivora, Felidae). Zoological Journal of the Linnean Society 140(2):207221.DOI: 10.1111/j.1096-3642.2003.00093.x.

Arilla M, Rosell J, Blasco R, Domínguez-Rodrigo M, Pickering TR. 2014. The “Bear” essentials: actualistic research on Ursus arctos arctos in the Spanish Pyrenees and its implications for paleontology and archaeology. PLoS One 9(7):e102457. DOI: 10.1371/journal.pone.0102457.

Bargo MS. 2003. Biomechanics and Palaeobiology of the Xenarthra: state of the art. In: Fariña RA, Vizcaíno SF, Storch G, eds. Morphological Studies in fossil and extant Xenarthra (Mammalia). Senckenbergiana biologica 83(1): 41-50. Frankfurt am Main.

Behrensmeyer AK. 1978. Taphonomic and Ecologic Information from Bone Weathering. Paleobiology 4:150-162. 
495 Biknevicius AR, Van Valkenburgh B, Walker J. 1996. Incisor size and shape: implications for 496 feeding behaviors in saber-toothed “cats". Journal of Vertebrate Paleontology 16(3):510-521.

497 Binder WJ, Van Valkenburgh B. 2010. A comparison of tooth wear and breakage in Rancho La 498 Brea sabertooth cats and dire wolves across time. Journal of Vertebrate Paleontology 30(1):255499 261.DOI: 10.1080/02724630903413016.

500 Binford LR.1981. Bones: Ancient Men and Modern Myths. New York: Academic Press.

501 Blumenschine RJ. 1986. Carcass consumption sequences and the archaeological distinction of 502 scavenging and hunting. Journal of Human Evolution 15(8):639-659.

503 Blumenschine RJ. 1987. Characteristics of an Early Hominid Scavenging Niche [and Comments 504 and Reply].Current Anthropology 28(4):383-407.

505 Bocherens H, Cotte M, Bonini R, Scian D, Straccia P, Soibelzon LH, Prevosti FJ. 2016.

506 Paleobiology of sabretooth cat Smilodon populator in the Pampean Region (Buenos Aires 507 Province, Argentina) around the Last Glacial Maximum: Insights from carbon and nitrogen stable 508 isotopes in bone collagen. Palaeogeography, Palaeoclimatology, Palaeoecology 449: 463-474. 509 DOI: 10.1016/j.palaeo.2016.02.017.

510 Bunn HT. 1986. Patterns of skeletal representation and hominid subsistence activities at Olduvai 511 Gorge, Tanzania, and Koobi Fora, Kenya. Journal of Human Evolution, 15(8), 673-690. 512 DOI:10.1016/S0047-2484(86)80004-5

513 Burke CC. 2013. Neotaphonomic analysis of the feeding behaviors and modification marks 514 produced by North American carnivores. Journal of Taphonomy 11(1): 1-20. 
515 Capaldo SD, Blumenschine RJ. 1994. A quantitative diagnosis of notches made by hammerstone 516 percussion and carnivore gnawing on bovid long bones. American Antiquity 59(4): 724-748.

517 Christiansen P, Harris JM. 2006. Body Size of Smilodon (Mammalia: Felidae). Journal of 518 Morphology 266:369-384. DOI: 10.1002/jmor.10384.

519 Christiansen P, Wroe S. 2007. Bite forces and evolutionary adaptations to feeding ecology in 520 carnivores. Ecology 88(2):347-358.DOI: 10.1890/0012-9658(2007)88[347:BFAEAT]2.0.CO;2.

521 Cione AL, Tonni EP, Soibelzon LH. 2009. Did humans cause large mammal Late Pleistocene522 Holocene extinction in South America in a context of shrinking open areas? In: Haynes G, ed. 523 American Megafaunal Extinctions at the End of the Pleistocene. Vertebrate Paleobiology and 524 Palaeontology Series. Springer Publishers, 125-144.

525 de Araújo Júnior HI, de Oliveira Porpino K, Paglarelli Bergqvist L. 2011. Marcas de dentes de 526 carnívoros/carniceiros em mamíferos pleistocênicos do Nordeste do Brasil. Revista Brasileira de 527 Paleontologia 14(3): 291-296.DOI: 10.4072/rbp.2011.3.08.

528 de los Reyes M, Poiré D, Soibelzon LH, Zurita AE, Arrouy MJ. 2013. First evidence of 529 scavenging of a glyptodont (Mammalia, Glyptodontidae) from the Pliocene of the Pampean 530 region (Argentina): taphonomic and paleoecological remarks. Palaeontología Electrónica 531 16(2):15A.

532 Delaney-Rivera C, Plummer TW, Hodgson JA, Forrest F, Hertel F, Oliver JS. 2009. Pits and 533 pitfalls: taxonomic variability and patterning in tooth mark dimensions. Journal of 534 Archaeological Science, 36(11): 2597-2608. DOI: 10.1016/j.jas.2009.08.001 
535 Dominato VH, Mothé D, Costa da Silva R, Dos Santos Avilla L. 2011. Evidence of scavenging 536 on remains of the gomphothere Haplomastodon waringi (Proboscidea: Mammalia) from the 537 Pleistocene of Brazil: Taphonomic and paleoecological remarks. Journal of South American 538 Earth Sciences 31:171-177. DOI: 10.1016/j.jsames.2011.01.002.

539 Domínguez-Rodrigo M, Gidna AO. Yravedra J, Musiba C. 2012. A comparative neo-taphonomic 540 study of felids, hyaenids and canids: an Analogical Framework Based on long bone Modification 541 Patterns. Journal of taphonomy 10(3-4):147-164.

542 Domínguez-Rodrigo M, Yravedra J, Organista E, Gidna A, Fourvel JB, Baquedano E. 2015. A 543 new methodological approach to the taphonomic study of paleontological and archaeological 544 faunal assemblages: a preliminary case study from Olduvai Gorge (Tanzania). Journal of 545 Archaeological Science 59: 35-53. DOI: 10.1016/j.jas.2015.04.007.

546 Domínguez-Rodrigo M, Piqueras A. (2003). The use of tooth pits to identify carnivore taxa in 547 tooth-marked archaeofaunas and their relevance to reconstruct hominid carcass processing 548 behaviours. Journal of Archaeological Science 30(11): 1385-1391. doi.org/10.1016/S0305549 4403(03)00027-X

550 Espigares MP, Martínez-Navarro B, Palmqvist P, Ros-Montoya S, Toro I, Agustí I, Sala R. 2013. 551 Homo versus Pachycrocuta: Earliest evidence of competition for and Elephant carcass between 552 scavengers at Fuente Nueva 3 (Orce, Spain). Quaternary International 295:113-125.DOI: 553 10.1016/j.quaint.2012.09.032

554 Fariña RA. 1996. Trophic relationships among Lujanian mammals. Evolutionary Theory 11: 125555134.

556 Fariña RA, Vizcaíno SF, de Iuliis G. 2013. Megafauna. Giant Beasts of Pleistocene South 557 America. Bloomington, Indiana: Indiana University Press. 
558 Fernández-Jalvo Y, Andrews P. 2003.Experimental effects of water abrasion on bone fragments.

559 Journal of Taphonomy 1(3): 147-163.

560 Fernández-Jalvo, Y., Andrews P. 2016. Atlas of Taphonomic Identifications. 1001+ Images of

561 fossil and recent mammal bone modification. Dordrecht: Springer Publishers.

562 Figueirido BF, Soibelzon LH. 2010. Inferring palaeoecology in extinct tremarctine bears

563 (Carnivora, Ursidae) using geometric morphometrics. Lethaia 43(2): 209-222. DOI:

564 10.1111/j.1502-3931.2009.00184.x.

565 Figueirido B, Martín-Serra A, Janis CM. 2016. Ecomorphological determinations in the absence 566 of living analogues: the predatory behaviour of the marsupial lion (Thylacoleocarnifex) as

567 revealed by elbow joint morphology. Paleobiology 43:508-531. DOI: 10.1017/pab.2015.55.

568 Fucks E, Deschamps CM. 2008. Depósitos Continentales Cuaternarios en el Noreste de la

569 Provincia de Buenos Aires. Revista de la Asociación Geológica Argentina 63(3): 326-343.

570 Hammer Ø, Harper DAT, Ryan PD. 2001. PAST: Paleontological statistics software package for

571 education and data analysis. Palaeontologia Electronica 4(1): 9pp

572 Haynes G. 1980. Evidence of carnivore gnawing on Pleistocene and Recent mammalian bones.

573 Paleobiology 6(3): 341-351.DOI: 10.1017/S0094837300006849.

574 Haynes G. 1982. Utilization and skeletal disturbances North American prey. Artic 35(2):266-281.

575 DOI: $10.14430 / \operatorname{arctic} 2325$. 
576 Haynes G. 1983. A guide for differentiating mammalian carnivore taxa responsible for gnaw

577 damage to herbivore limb bones. Paleobiology 9(2):164-172. DOI: 10.1017/S0094837300007545

578 Haynes G, Klimowicz J. 2015. Recent elephant-carcass utilization as a basis for interpreting 579 mammoth exploitation. Quaternary International 359-360:19-37. DOI:

$580 \quad 10.1016 /$ j.quaint.2013.12.040

581 Kaufmann C A, Rafuse DJ, González ME, Álvarez MC, Massigoge A, Scheifler NA, Gutiérrez 582 MA. 2016. Carcass utilization and bone modifications on guanaco killed by puma in northern 583 Patagonia, Argentina. Quaternary International. In press. DOI: 10.1016/j.quaint.2016.03.003

584 Labarca R, Recabarren OP, Canales-Brellenthin P, Pino M. 2014. The gomphotheres 585 (Proboscidea: Gomphotheriidae) from Pilauco site: Scavenging evidence in the Late Pleistocene 586 of the Chilean Patagonia. Quaternary International 352:75-84. DOI:

587 10.1016/j.quaint.2014.10.027.

588 Lyman R.L. 1994. Vertebrate Taphonomy. Cambridge Manuals in Archaeology. Cambridge: 589 Cambridge University Press.

590 Marean CW, Ehrhardt CL. 1995. Paleoanthropological and paleoecological implications of the 591 taphonomy of a sabertooth's den. Journal of Human Evolution 29(6):515-547. DOI:

$592 \quad 10.1006 /$ jhev.1995.1074

593 Martin FM. 2008. Bone crunching felids at the end of the Pleistocene in Fuego-Patagonia, Chile. 594 Journal of Taphonomy 6 (3-4): 337- 372.

595 Martin FM. 2016. Cueva del Milodón. The hunting grounds of the Patagonian panther. 596 Quaternary International. In press. DOI: org/10.1016/j.quaint.2016.05.005 
597 Mcafee R K. 2009. Reassessment of the cranial characters of Glossotherium and Paramylodon 598 (Mammalia: Xenarthra: Mylodontidae). Zoological Journal of the Linnean Society 155(4): 885903. DOI: 10.1111/j.1096-3642.2008.00468.x

600 Muñoz AS, Mondini M, Durán V, Gasco A. 2008. Los pumas (Puma concolor) como agentes 601 tafonómicos. Análisis actualístico de un sitio de matanza en los Andes de Mendoza, Argentina. 602 Geobios 41:123-131.DOI: 10.1016/j.geobios.2006.11.010.

603 Olsen SL, Shipman P. 1988. Surface modification on bone: Trampling versus butchery. Journal 604 of Archaeological Science 15: 535-553. DOI: 10.1016/0305-4403(88)90081-7.

605 Palmqvist, P., Torregrosa, V., Pérez-Claros, J. A., Martínez-Navarro, B., \& Turner, A. 2007. A re606 evaluation of the diversity of Megantereon (Mammalia, Carnivora, Machairodontinae) and the 607 problem of species identification in extinct carnivores. Journal of Vertebrate Paleontology, 27(1), $608 \quad 160-175$.

Palmqvist P, Martínez-Navarro B, Pérez-Claros JA, Torregrosa V, Figueirido B, Jiménez-Arenas JM, Patrocinio Espigares M, Ros-Montoya S, De Renzi M. 2011. The giant hyena Pachycrocuta brevirostris: modelling the bone-cracking behavior of an extinct carnivore. Quaternary International 243(1): 61-79. DOI: 10.1016/j.quaint.2010.12.035.

Pickering TR, Domínguez-Rodrigo M, Egeland CP, Brain CK. 2004. Beyond leopards: tooth marks and the contribution of multiple carnivore taxa to the accumulation of the Swartkrans Member 3 fossil assemblage. Journal of Human Evolution 46(5): 595-604. DOI: org/10.1016/j.jhevol.2004.03.002

Pobiner, B.L., Blumenschine, R.J., 2003. A taphonomic perspective on Oldowan hominid encroachment on the carnivoran paleoguild. Journal of Taphonomy 1(2):115-141. 
619 Politis GG, Gutiérrez MA, Rafuse DJ, Blasi A. 2016. The Arrival of Homo sapiens into the 620 Southern Cone at 14,000 Years Ago. PloS one, 1, 1(9): e0162870. DOI:

621 doi:10.1371/journal.pone.0162870

622 Prevosti FJ, Palmqvist P. 2001. Análisis ecomorfológico del cánido hipercarnívoro Theriodictis 623 platensis Mercerat (Mammalia, Carnivora), basado en un nuevo ejemplar del Pleistoceno de 624 Argentina. Ameghiniana 38(4): 375-384.

625 Prevosti FJ, Zurita AE, Carlini AA. 2005. Biostratigraphy, s3stematics, and paleoecology of 626 Protocyon Giebel, 1855 (Carnivora, Canidae) in South America. Journal of South American 627 Earth Sciences 20:5-12. DOI: 10.1016/j.jsames.2005.05.005.

628 Prevosti FJ, Vizcaíno S. 2006. Paleoecology of the large carnivore guild from the Late 629 Pleistocene of Argentina. Acta Palaeontologica Polonica 51(3):407-422.

630 Prevosti FJ, Tonni, EP, Bidegain JC. 2009. Stratigraphic range of the large canids (Carnivora, 631 Canidae) in South America, and its relevance to quaternary biostratigraphy. Quaternary 632 International, 210(1): 76-81. DOI: org/10.1016/j.quaint.2009.06.034

633 Prevosti FJ, Schubert BW. 2013. First taxon date and stable isotopes $(\delta 13 \mathrm{C}, \delta 15 \mathrm{~N})$ for the large 634 hypercarnivorous South American canid Protocyon troglodytes (Canidae, Carnivora). Quaternary 635 International 305:67-73. DOI: 10.1016/j.quaint.2012.07.003.

636 Sala N, Arsuaga JL, Haynes G. 2014. Taphonomic comparison of bone modifications caused by 637 wild and captive wolves (Canis lupus). Quaternary International 330: 126-135. DOI: 638 10.1016/j.quaint.2013.08.017. 
639 Sala N, Arsuaga JL. 2016. Regarding beasts and humans: A review of taphonomic works with 640 living carnivores. Quaternary International, in press. DOI: 10.1016/j.quaint.2016.03.011

641 Saladié P, Huguet R, Díez C, Rodríguez-Hidalgo A, Carbonell E. 2013. Taphonomic 642 modifications produced by modern brown bears (Ursus arctos). International Journal of 643 Osteoarchaeology 23:13-33.DOI: 10.1002/oa.1237.

644 Scanferla A, Bonini R, Pomi L, Fucks E, Molinari A. 2013. New Late Pleistocene megafaunal 645 assemblage with well-supported chronology from the Pampas of Southern South America. 646 Quaternary International 305:97-103. DOI: 10.1016/j.quaint.2012.08.005.

647 Shipman P. 1981.Life History of a Fossil: An Introduction to Taphonomy and Paleoecology. 648 Cambridge: Harvard University Press.

649 Soibelzon LH, Grinspan GA, Bocherens H, Acosta WG, Jones W, Blanco ER, Prevosti F. 2014. 650 South American giant short-faced bear (Arctotherium angustidens) diet: evidence from pathology, 651 morphology, stable isotopes, and biomechanics. Journal of Paleontology 88(6):1240-1250. DOI: $65210.1666 / 13-143$.

653 Tonni EP. 2009. Los mamíferos del Cuaternario de la región pampeana de Buenos Aires, 654 Argentina. In: Ribeiro AM, Girardi Bauermann S., Saldanha Scherer C., Eds. Quaternario do Rio 655 Grande do Sul. Integrando Conhecimentos. Porto Alegre: Monografías da Sociedades Brasileira 656 de Paleontologia, 193-205.

657 Tonni EP. 2011. Ameghino y la estratigrafía pampeana un siglo después. Publicación Especial de 658 la Asociación Paleontológica Argentina, Vida y Obra de Florentino Ameghino, 69-79. 
659 Tonni EP, Duarte RA, Carbonari JE, Figini AJ. 2003. New radiocarbon chronology for the 660 Guerrero Member of the Luján Formation (Buenos Aires, Argentina): Palaeoclimatic 661 significance. Quaternary International 109-110:45-48. DOI: 10.1016/S1040-6182(02)00201-X.

662 Van Valkenburgh, B, Hertel F. 1993. Tough times at La Brea: tooth breakage in large carnivores 663 of the late Pleistocene. Science 261:456-459. DOI: 10.1126/science.261.5120.456.

664 Van Valkenburgh B, Hayward MW, Ripple WJ, Meloro C, Roth VL. 2016. The impact of large 665 terrestrial carnivores on Pleistocene ecosystems. Proceedings of the National Academy of 666 Sciences 113(4):862-867. DOI: 10.1073/pnas.1502554112

667 White PA, Diedrich CG. 2012. Taphonomy story of a modern African elephant Loxodonta 668 africana carcass on a lakeshore in Zambia (Africa). Quaternary International 276-277: 287-296. 669 DOI: 10.1016/j.quaint.2012.07.025.

670 Yravedra J, Lagos L, Bárcena F. 2011. A Taphonomic study of wild wolf (Canis lupus) 671 Modification of horse bones in Northwestern. Spain. Journal of Taphonomy 9(1): 37-65.

\section{Table captions}

673 Table 1. Megamammal bones with museums assignation and current biostratigraphical 674 determination.

675 Table 2. Measurements of pits, punctures and scores. Presence of furrowing or crenulated edges was also indicated.

677 Table 3. Body size categories for Pampean carnivores (based on Bunn, 1986)

678 Table 4. South American sites with reported dimensions of pitting and/or punctures (as cited in 679 the original publication). ML: Maximum length; MW: Maximum width; MA A: Major axis; MI 680 A: Minor axis. Measurements marked with * were used for comparative purposes. 


\section{Figure captions}

682 Figure 1. South American map showing the three sites mentioned in the text. In Brazil: 1, Tanque 683 do Jirau; 2, Águas de Araxá. In the Pampean region: 3, Salado River and material found in 684 different collections of this study; 4, Olavarria and Arroyo Seco 2. In the Patagonian region: 5, 685 Pilauco; 6, Lago Sofía cave, Milodón cave, Dos Herraduras rockshelter, Chingues cave, Puma 686 cave, Fell cave, Tres Arroyos rockshelter.

687 Figure 2. Pleistocene Formations, Stage/Age and the locations of the collections over time. 688 Abbreviations: Ma, million years of ago.

Figure 3. Box plot diagram showing the Log-transformed area of the pits/punctures on the bones from MCNV 64-492, MNHN.F. PAM 119, MLP, Xen 30-12 (de los Reyes et al., 2013, Table 1), Cueva del Milodón (Martin, 2016) and Swartkrans Member 3 (Pickering et al., 2004, Appendix A, column of large mammals) (Generated using the PAST program, Version 3.14; Hammer, 693 Harper \& Ryan, 2001).

Figure 4. Right tibia of cf. Scelidotheriinae gen., 64-492 from MCNV, posterior-medial view, indicating the different marks described in the text: A) distal epiphysis, the rectangle and zoom indicate the four linearly-positioned pits; B) metadiaphysis with the U-shaped parallel scores circled; C) furrowing of the distal metadiaphysis, with a circle indicating the parallel, V-shaped teeth marks on the posterior face; D) medial face of the diaphysis with a magnified image of one of the three thick grooves; E) furrowing of the proximal metadiaphysis.

Figure 5. Left humerus Glossotherium robustum, MNHN.F.PAM 119 from MNHN, anterior view, indicating the different marks described in the text: A) front view of distal articular face; B) amplification of trochlear region with punctures and scratches; C) amplification of condyle with scoring; D) wide grooves on the lateral face.

Figure 6. Left distal humerus of Glossotherium robustum, 1908. XI.110 from MNW: A) anterior face; B) posterior face, indicating the puncture; C) amplification of the posterior rim; and D) indication of the flaked border.

707 Figure 7. Condyle of distal femur of Toxodontidae, 15-I-20-32 with elongated and U-shaped 708 scratches: A) lateral face; B) anterior view with scores; C) medial view. 
709 Figure 8. Bone shafts showing carnivore intervention from MLP: A) MLP 15-I-20-35 with spiral

710 fracture, amplifications of the internal notch and the cortical face with scoring; B) MLP 15-I-20-

71134 with spiral fracture, notches can be observed on the medullar face, amplification of light

712 pitting in the cortical face; C) MLP 15-I-20-33 with spiral fracture

713 Figure 9. Bone shafts showing carnivore intervention from MLP with spiral fracture and

714 magnification of crenulated edge: A) MLP 15-I-20-37; B) MLP 15-I-20-38

715 Figure 10. Indeterminate fragment of bone with puncture and amplification of the puncture with

716 Dino-Lite measurements: A) MLP 15-I-20-36; B) MLP 15-I-20-39. 


\section{Table $\mathbf{1}$ (on next page)}

Table 1.

Megamammal bones with museums assignation and current biostratigraphical determination. 
1 Table 1. Megamammal bones with museums assignation and current biostratigraphical

2 determination.

\begin{tabular}{|c|c|c|c|c|}
\hline MUSEUM & $\begin{array}{c}\text { MUSEUM } \\
\text { ABBREVIATION }\end{array}$ & TAXON & $\begin{array}{c}\text { MUSEUM } \\
\text { ASIGNATION }\end{array}$ & $\begin{array}{l}\text { BIOSTATIGRAPHICAL } \\
\text { DETERMINATION }\end{array}$ \\
\hline $\begin{array}{c}\text { Museo de Ciencias } \\
\text { Naturales de Valencia }\end{array}$ & MCNV & $\begin{array}{c}\text { cf. } \\
\text { Scelidotheriinae } \\
\text { gen. }\end{array}$ & - & $\begin{array}{c}\text { Ensenadan to Lujanian } \\
\text { Stage/Age }\end{array}$ \\
\hline $\begin{array}{c}\text { Muséum National d' } \\
\text { Histoire Naturelle }\end{array}$ & MNHN & $\begin{array}{c}\text { Glossotherium } \\
\text { robustum }\end{array}$ & Pampean & $\begin{array}{c}\text { Bonarian and Lujanian } \\
\text { Stage/Age }\end{array}$ \\
\hline $\begin{array}{l}\text { Naturhistorisches Museum } \\
\text { Wien }\end{array}$ & NMW & $\begin{array}{l}\text { Glossotherium } \\
\text { robustum }\end{array}$ & $\begin{array}{l}\text { Diluvium- Upper } \\
\text { Pampean }\end{array}$ & Bonarian Stage/Age \\
\hline Museo de La Plata & MLP & Toxodontidae & Ensenadan & Ensenadan Stage/Age \\
\hline
\end{tabular}

3 


\section{Table 2 (on next page)}

Table 2.

Measurements of pits, punctures and scores. Presence of furrowing or crenulated edges was also indicated. 
1 Table 2. Measurements of pits, punctures and scores. Presence of furrowing or crenulated edges

2 was also indicated.

\begin{tabular}{|c|c|c|c|c|c|c|}
\hline $\begin{array}{l}\text { MUSEUM/ } \\
\text { SPECIMEN }\end{array}$ & SPECIES & ELEMENT & $\begin{array}{c}\text { PITTING/ } \\
\text { PUNCTURES }\end{array}$ & SCRATCHES/ SCORES & $\begin{array}{l}\text { CRENUL } \\
\text { ATED }\end{array}$ & $\begin{array}{c}\text { FURR } \\
\text { OWI } \\
\text { NG }\end{array}$ \\
\hline $\begin{array}{l}\text { MCNV (64- } \\
\text { 492) }\end{array}$ & $\begin{array}{c}\text { cf. } \\
\text { Scelidotheriinae } \\
\text { gen. }\end{array}$ & Right tibia & $\begin{array}{c}4 \times 3 \mathrm{~mm} / 5 \times 3 \\
\mathrm{~mm} / 9 \times 6 \mathrm{~mm} / 5 \times 4 \\
\mathrm{~mm} . \text { Pittings on } \\
\text { distal articular face, } \\
\text { medial edge }\end{array}$ & $\begin{array}{l}\text { (i) } 20 \times 10 \mathrm{~mm} \text {. Score on distal articular } \\
\text { face, lateral edge. } \\
\text { (ii) } 45 \times 10 \times 4 \mathrm{~mm} / 13 \times 10 \mathrm{~mm} / 20 \times 13 \\
\mathrm{~mm} \text {. Grooves medial face of the diaphysis } \\
\text { (iii) } 15 \times 4 \mathrm{~mm} \text { (Five marks of distal } \\
\text { posterior face) and } 15 \times 5 \mathrm{~mm} \text { (Two marks } \\
\text { proximal posterior face). }\end{array}$ & $\mathrm{x}$ & $\mathrm{x}$ \\
\hline $\begin{array}{l}\text { MNHN } \\
\text { (MNHN.F. } \\
\text { PAM 119) }\end{array}$ & $\begin{array}{l}\text { Glossotherium } \\
\text { robustum }\end{array}$ & $\begin{array}{c}\text { Left } \\
\text { humerus }\end{array}$ & $\begin{array}{c}8 \times 6 \mathrm{~mm} / 7 \times 7 \\
\mathrm{~mm} / 6 \times 5 \mathrm{~mm} / 3 \times \\
3 \mathrm{~mm} . \text { Punctures in } \\
\text { trochlear region }\end{array}$ & $\begin{array}{l}\text { (i) } 45 \times 10 \mathrm{~cm} \text { groove in the condyle } \\
\text { (ii) } 10 \times 7 \mathrm{~mm} / 15 \times 6 \mathrm{~mm} / 15 \times 10 \mathrm{~mm} \\
\text { scores in condyle }\end{array}$ & - & $\mathrm{x}$ \\
\hline $\begin{array}{c}\text { MNW } \\
(1908 . X I .110)\end{array}$ & $\begin{array}{l}\text { Glossotherium } \\
\text { robustum }\end{array}$ & $\begin{array}{l}\text { Left distal } \\
\text { humerus }\end{array}$ & $8,5 \times 6 \mathrm{~mm}$ & - & $\mathrm{x}$ & $\mathrm{x}$ \\
\hline $\begin{array}{l}\text { MLP (MLP 15- } \\
\text { I-20-32) }\end{array}$ & Toxodontidae & $\begin{array}{l}\text { Femur } \\
\text { condyle }\end{array}$ & - & $\begin{array}{l}\text { Three scratches of } 40 \times 5 \mathrm{~mm} / \text { Five } \\
\text { scratches of } 15 \times 5 \mathrm{~mm}\end{array}$ & - & - \\
\hline $\begin{array}{l}\text { MLP (MLP 15- } \\
\text { I-20-36) }\end{array}$ & Indeterminate & $\begin{array}{c}\text { Indeterminat } \\
\mathrm{e}\end{array}$ & $8 \times 8 \mathrm{~mm}$ & - & - & - \\
\hline $\begin{array}{l}\text { MLP (MLP 15- } \\
\text { I-20-39) }\end{array}$ & Indeterminate & $\begin{array}{c}\text { Indeterminat } \\
\mathrm{e}\end{array}$ & $4,5 \times 4 \mathrm{~mm}$ & - & - & - \\
\hline $\begin{array}{l}\text { MLP (MLP 15- } \\
\text { I-20-40) }\end{array}$ & Indeterminate & Diaphysis & $\begin{array}{c}3.5 \times 2 \mathrm{~mm} / 6.5 \times 4 \\
\mathrm{~mm}\end{array}$ & - & - & - \\
\hline $\begin{array}{l}\text { MLP (MLP 15- } \\
\text { I-20-41) }\end{array}$ & Indeterminate & Diaphysis & $2 \times 2 \mathrm{~mm}$ & - & - & - \\
\hline
\end{tabular}




\section{Table 3 (on next page)}

Table 3.

Body size categories for Pampean carnivores (based on Bunn, 1986) 
1 Table 3. Body size categories for Pampean carnivores (based on Bunn, 1986)

2

PLEISTOCENE PAMPEAN CARNIVORES

Dusicyon avus

Protocyon

Canis nehringui

Theriodictis platensis

Puma concolor

A. vetustum/ $A$. bonariense/ $A$. tarijense

Panthera onca

Smilodon populator

Arctotherium angustidens
BODY SIZE (in kg.)

BODY SIZE CATEGORIES

Size 1

Size 2

Size 2

Size 2

Size 2

Size $3 \mathrm{a}$

Size $3 \mathrm{a}$

220-360 up to 400

Size $3 b /$ Size 4

Size 5 


\section{Table 4 (on next page)}

Table 4.

South American sites with reported dimensions of pitting and/or punctures (as cited in the original publication). ML: Maximum length; MW: Maximum width; MA A: Major axis; MI A: Minor axis. Measurements marked with * were used for comparative purposes. 
1 Table 4. South American sites with reported dimensions of pitting and/or punctures (as cited in 2 the original publication). ML: Maximum length; MW: Maximum width; MA A: Major axis; MI 3 A: Minor axis. Measurements marked with * were used for comparative purposes.

4

\begin{tabular}{|c|c|c|c|c|}
\hline SITE & SPECIES & CARNIVORE & PUNCTURE/PITTING SIZE (in mm) & REFERENCES \\
\hline Olavarría & $\begin{array}{l}\text { cf. Eosclerocalyptus lineatus } \\
\text { (Hoplophorini) }\end{array}$ & Chapalmalania & $\begin{array}{l}\text { ML 8.67/ MW } 4.38 \text { / Area mm2 33.93* } \\
\text { ML 11.07/ MW } 4.32 \text { / Area mm2 45.56* } \\
\text { ML 7.98/ MW } 1.95 \text { / Area mm2 10.92* } \\
\text { ML 6.97/ MW 4.63/ Area mm2 30.98* } \\
\text { ML 8.83/ MW } 1.93 \text { / Area mm2 13.02* } \\
\text { ML 7 82/ MW 2.80 / Area mm2 17.12* }\end{array}$ & $\begin{array}{c}\text { de los Reyes et al., } \\
2013 \\
\text { de los Reyes et al., } \\
2013 \\
\text { de los Reyes et al., } \\
2013 \\
\text { de los Reyes et al., } \\
2013 \\
\text { de los Reyes et al., } \\
2013 \\
\text { de los Reyes et al., } \\
2013\end{array}$ \\
\hline $\begin{array}{c}\text { Arroyo } \\
\text { Seco }\end{array}$ & Equidae & - & $\begin{array}{c}\text { Average: MA A (long) 7.383/ MI A (wide) } \\
5.727\end{array}$ & Politis et al., 2016 \\
\hline $\begin{array}{l}\text { Mylodon } \\
\text { Cave }\end{array}$ & Mylodon darwini & $\begin{array}{l}\text { Panthera onca } \\
\text { mesembrina }\end{array}$ & $\begin{array}{c}12.27 \text { diameter } \\
4.34 \text { to } 9.05 \\
41.63 \times 30.36^{*} \\
23.37 \times 21.86^{*} \\
7.10 \times 5.01^{*} \\
55.30 \times 40.29^{*} \\
10.61 \times 7.46^{*} \\
6.13 \times 5.14^{*} \\
15.09 \times 4.40^{*} \\
17.56 \times 13.43^{*} \\
7.99 \times 8.64^{*} \\
5.17 \times 4.99^{*} \\
6.84 \times 8.30^{*}\end{array}$ & $\begin{array}{c}\text { Martin, 2008, } 2016 \\
\text { Martin, 2008 } \\
\text { Martin, 2016 } \\
\text { Martin, } 2016 \\
\text { Martin, } 2016 \\
\text { Martin, } 2016 \\
\text { Martin, } 2016 \\
\text { Martin, } 2016 \\
\text { Martin, } 2016 \\
\text { Martin, } 2016 \\
\text { Martin, } 2016 \\
\text { Martin, } 2016 \\
\text { Martin, } 2016\end{array}$ \\
\hline $\begin{array}{l}\text { Chingues } \\
\text { Cave }\end{array}$ & Hippidion saldiasi & $\begin{array}{l}\text { Panthera onca } \\
\text { mesembrina }\end{array}$ & $\begin{array}{c}9 \times 7.60 \\
8.13 \times 4.79 \\
4.9 \times 4.2 \\
\end{array}$ & $\begin{array}{l}\text { Martin, } 2008 \\
\text { Martin, } 2008 \\
\text { Martin, } 2008\end{array}$ \\
\hline Pilauco & Gomphotheriidae & Felidae & $\begin{array}{c}10.24 \times 11.71 \\
8.84 \times 9.71\end{array}$ & $\begin{array}{l}\text { Labarca et al., } 2014 \\
\text { Labarca et al., } 2014\end{array}$ \\
\hline $\begin{array}{l}\text { Águas de } \\
\text { Araxá }\end{array}$ & Haplomastodon waringi & $\begin{array}{l}\text { Protocyon } \\
\text { troglodytes }\end{array}$ & $\begin{array}{l}\text { Average diameter } 5 \\
\text { Average diameter } 6\end{array}$ & $\begin{array}{c}\text { Dominato el al., } \\
2011 \\
\text { Dominato el al., } \\
2011\end{array}$ \\
\hline
\end{tabular}




\section{Figure 1}

Figure 1.

South American map showing the three sites mentioned in the text. In Brazil: Tanque do

Jirau, Águas de Araxá. In the Pampean region, Salado River and material found in different collections of this study, Olavarria and Arroyo Seco 2. In the Patagonian region: Pilauco, Lago Sofía cave, Milodón cave, Dos Herraduras rockshelter, Chingues cave, Puma cave, Fell cave, Tres Arroyos rockshelter. Image modified from Wikipedia (https://commons.wikimedia.org/wiki/File:BlankMap-Americas.svg). 

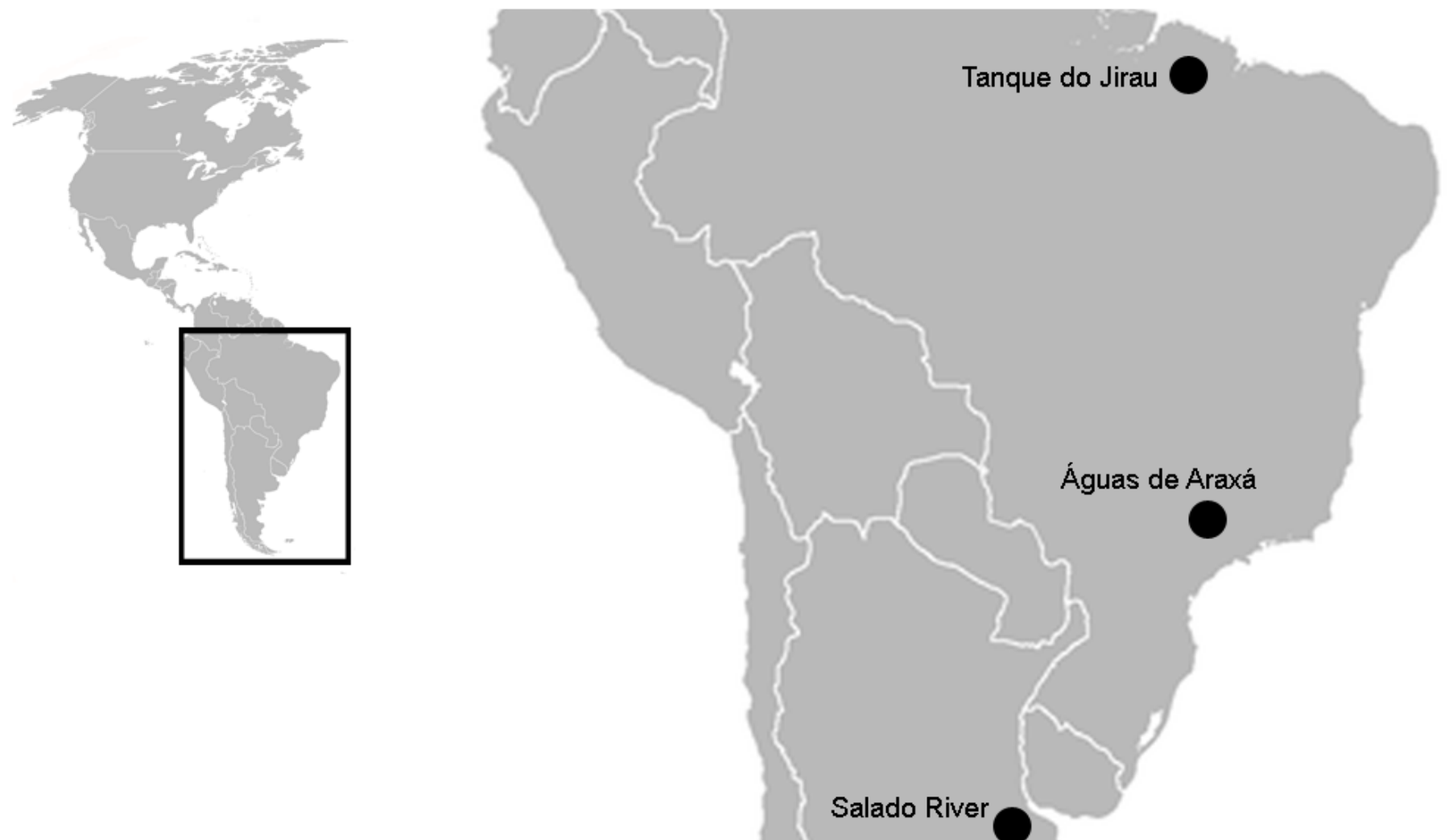

Lago Sofía 4 cave, Milodón cave, Dos Herraduras rockshelter, Chingues cave, Puma cave, Fell cave, Tres Arroyos rockshelter

Olavarría and Arroyo Seco 2

Pilauco
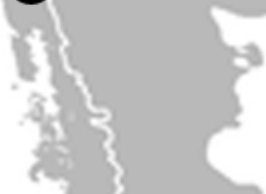
Figure 2

Figure 2.

Pleistocene Formations, Stage/Age and the locations of the collections over time.

Abbreviations: Ma, million years of ago

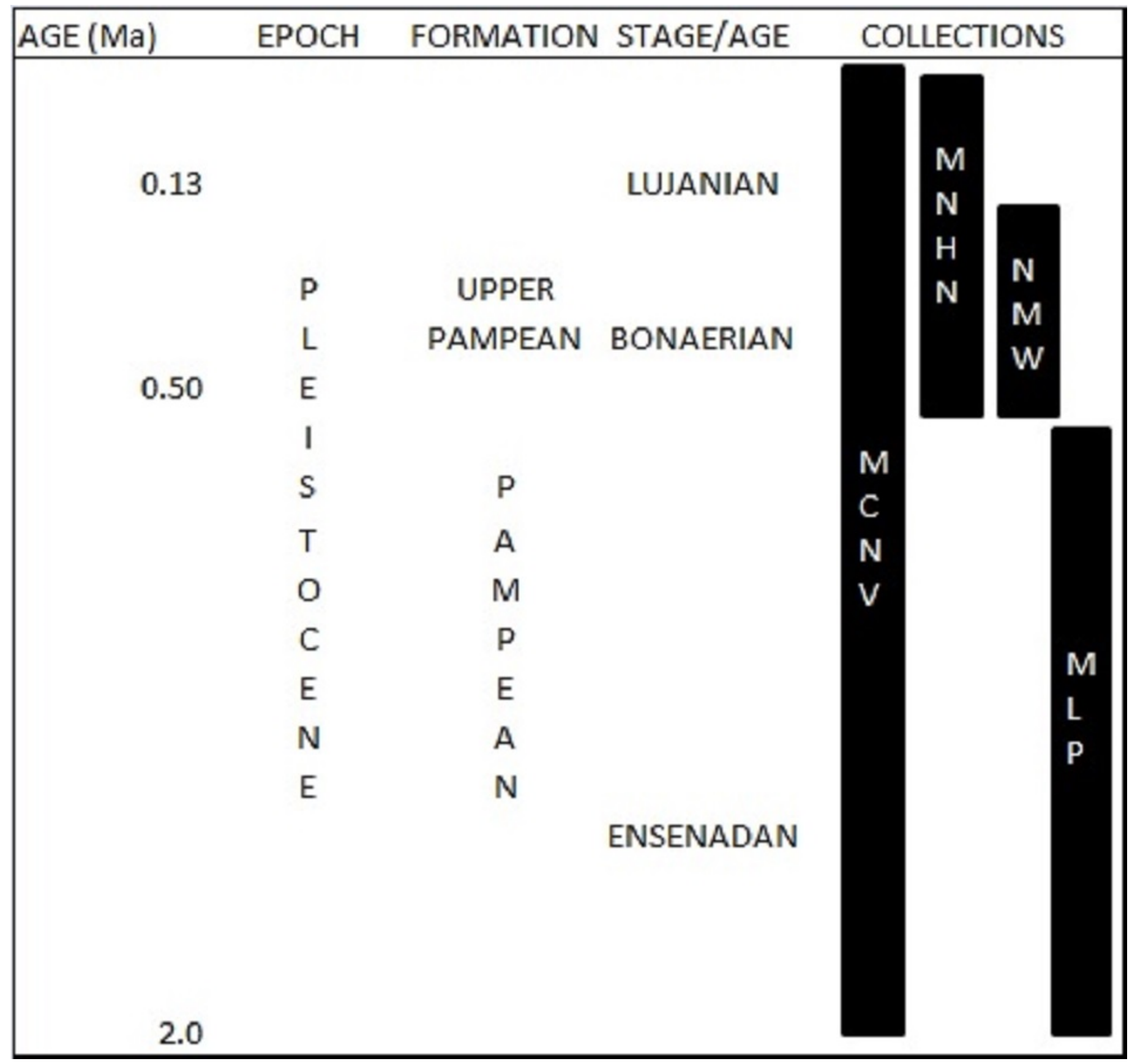


Figure 3

Figure 3.

Box plot diagram showing the Log-transformed area of the pits/punctures on the bones from MCNV 64-492, MNHN.F. PAM 119, MLP, Xen 30-12 (de los Reyes et al., 2013, Table 1), Cueva del Milodón (Martin, 2016) and Swartkrans Member 3 (Pickering et al., 2004, Appendix A, column of large mammals) (Generated using the PAST program, Version 3.14; Hammer, Harper \& Ryan, 2001).

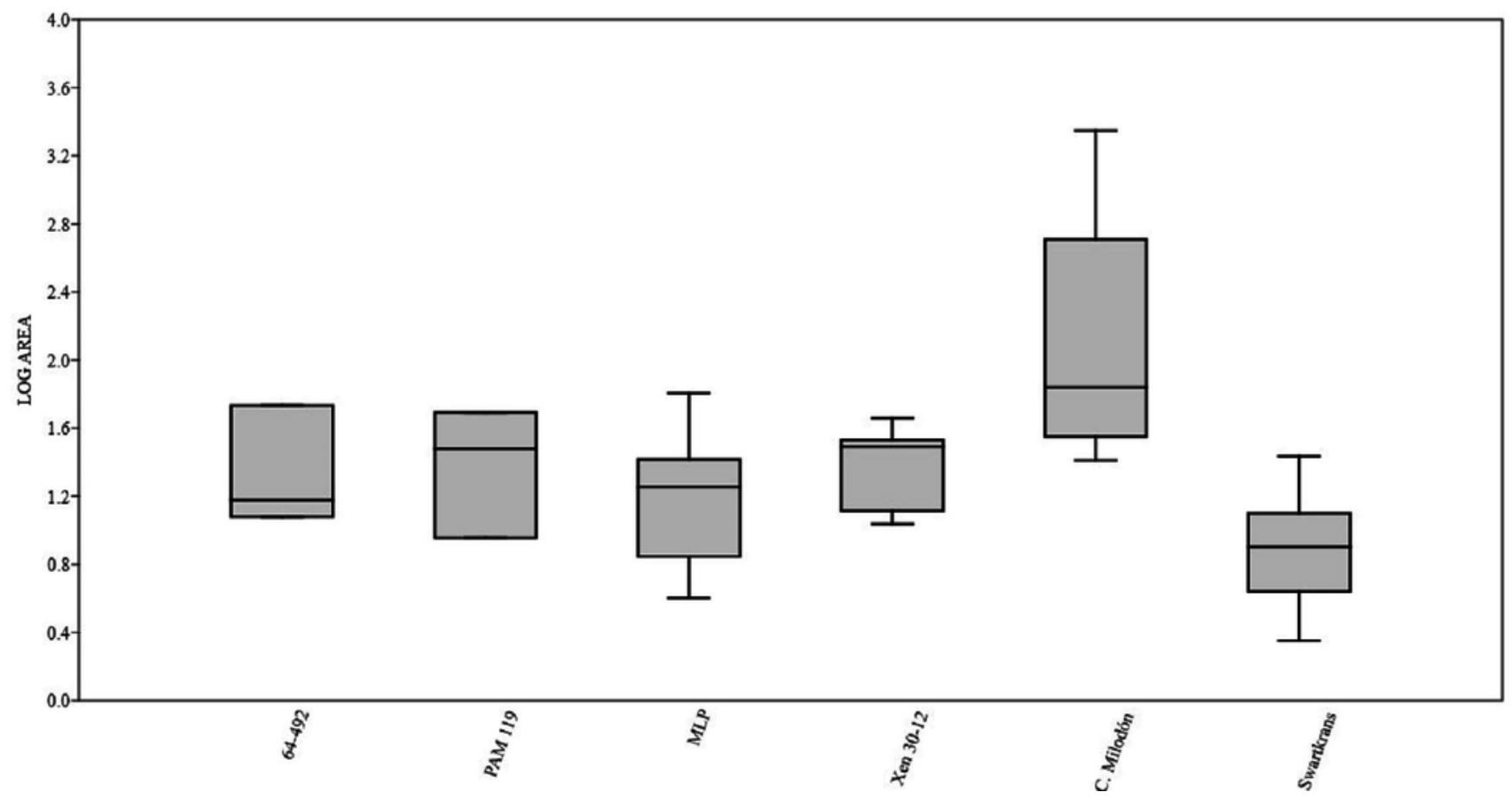




\section{Figure 4}

Figure 4.

Right tibia of cf. Scelidotheriinae gen., 64-492 from MCNV, posterior-medial view, indicating the different marks described in the text: A) distal epiphysis, the rectangle and zoom indicate the four linearly-positioned pits; B) metadiaphysis with the U-shaped parallel scores circled; C) furrowing of the distal metadiaphysis, with a circle indicating the parallel, V-shaped teeth marks on the posterior face; D) medial face of the diaphysis with a magnified image of one of the three thick grooves; E) furrowing of the proximal metadiaphysis. 


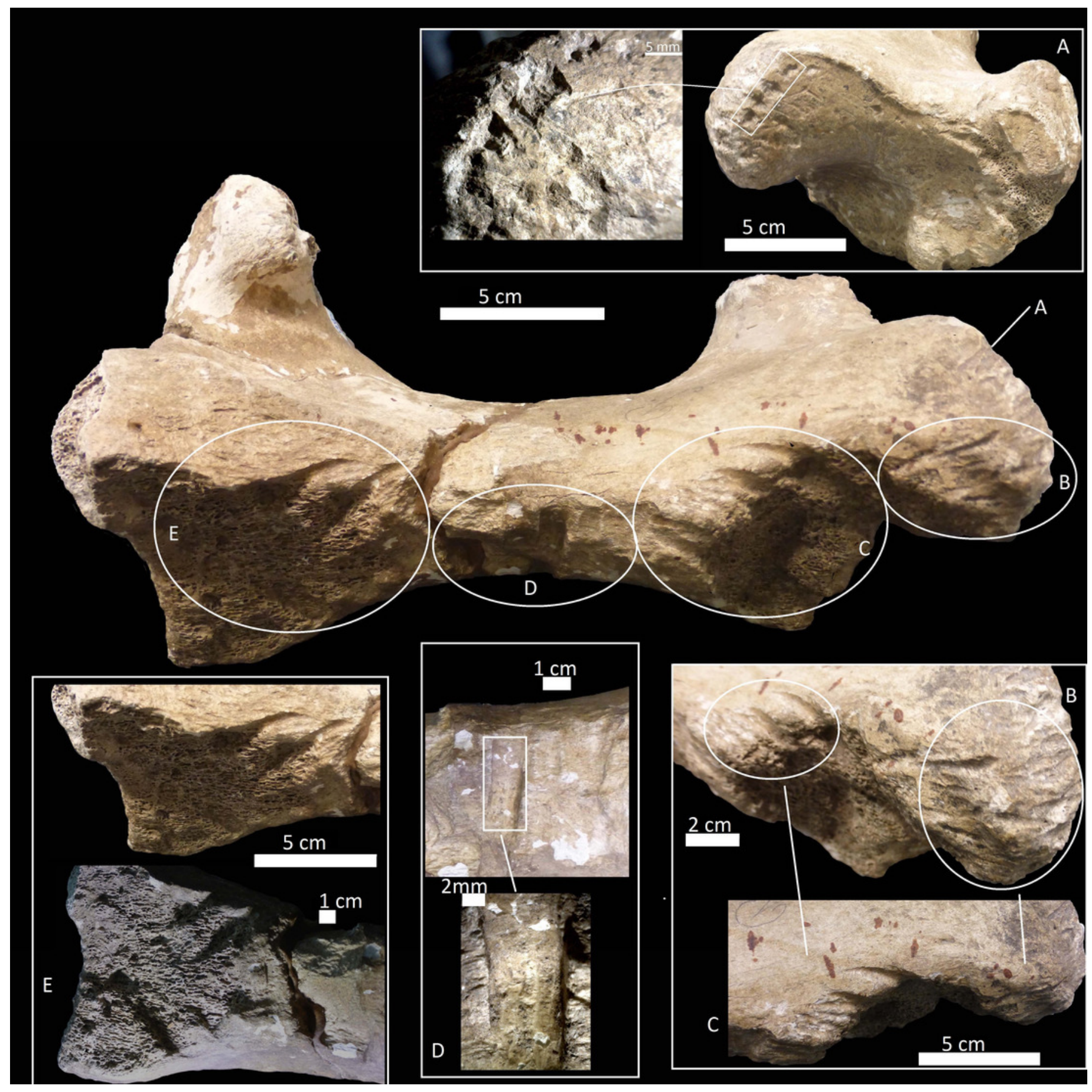




\section{Figure 5}

Figure 5.

Left humerus Glossotherium robustum, MNHN.F.PAM 119 from MNHN, anterior view, indicating the different marks described in the text: A) front view of distal articular face; B) amplification of trochlear region with punctures and scratches; C) amplification of condyle with scoring; D) wide grooves on the lateral face.

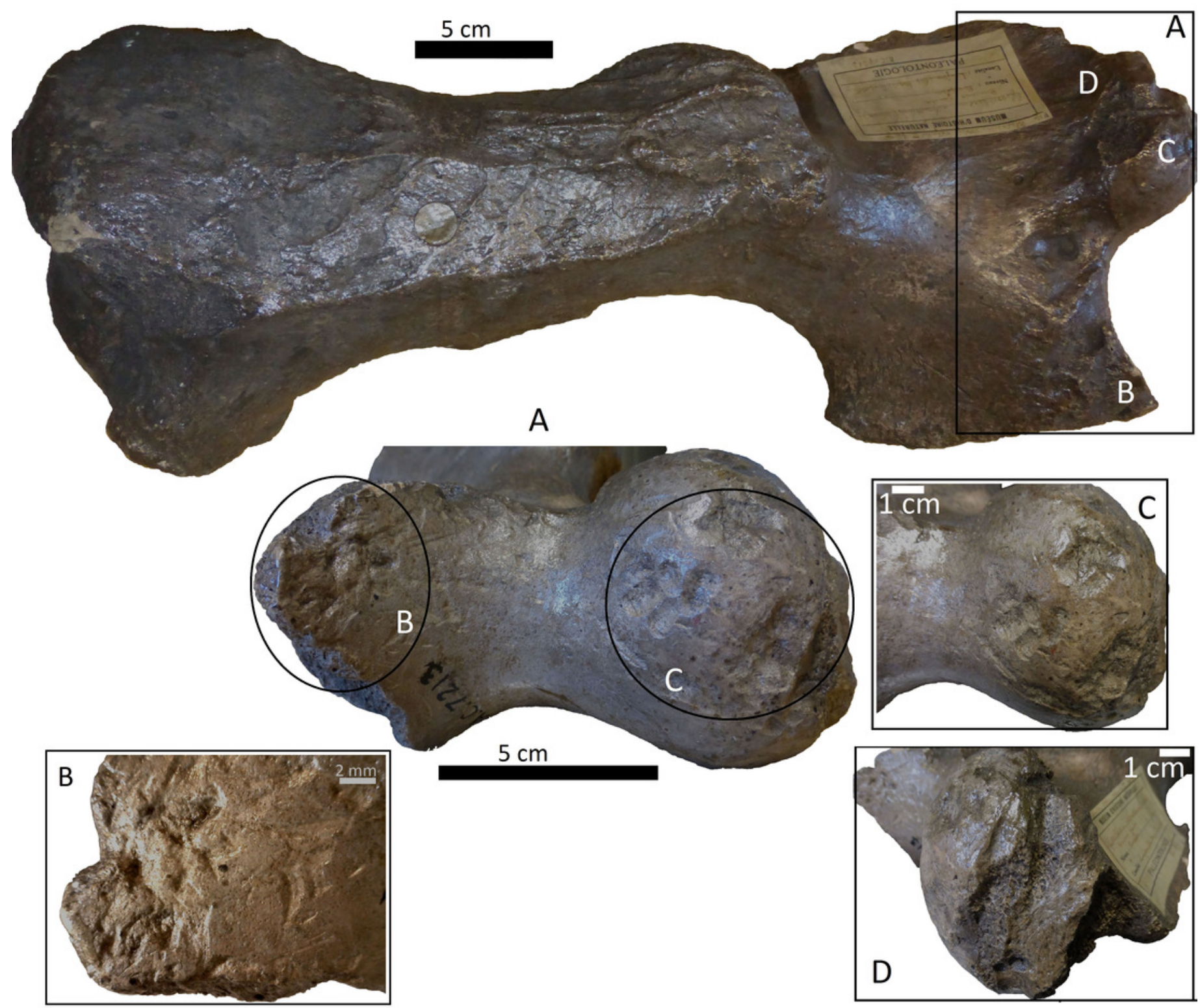




\section{Figure 6}

Figure 6.

Left distal humerus of Glossotherium robustum, 1908. XI.110 from MNW: A) anterior face; B) posterior face, indicating the puncture; C) amplification of the posterior rim; and D) indication of the flaked border. 


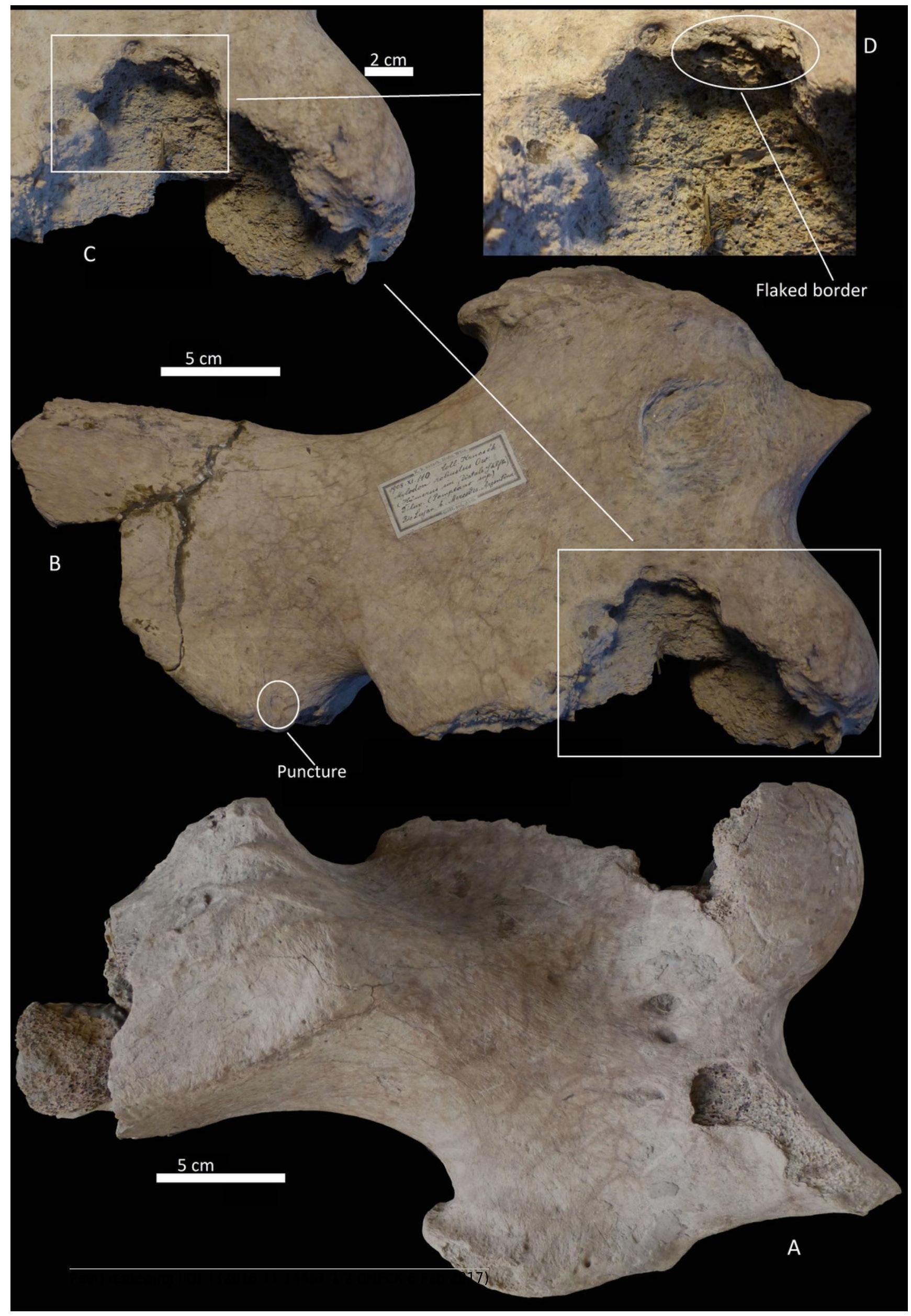




\section{Figure 7}

Figure 7.

Condyle of distal femur of Toxodontidae, 15-I-20-32 with elongated and U-shaped scratches:

A) lateral face; B) anterior view with scores; C) medial view.
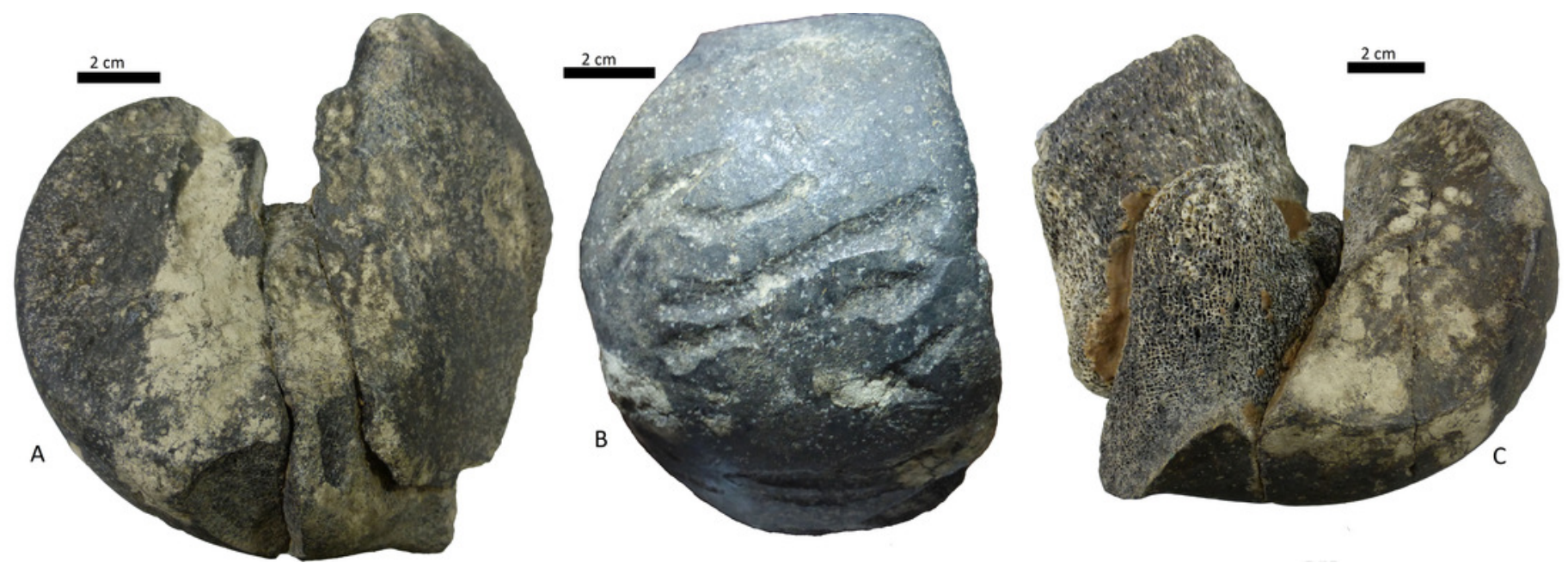


\section{Figure 8}

Figure 8.

Bone shafts showing carnivore intervention from MLP: A) MLP 15-I-20-35 with spiral fracture, amplifications of the internal notch and the cortical face with scoring; B) MLP 15-I-20-34 with spiral fracture, notches can be observed on the medullar face, amplification of light pitting in the cortical face; C) MLP 15-I-20-33 with spiral fracture 

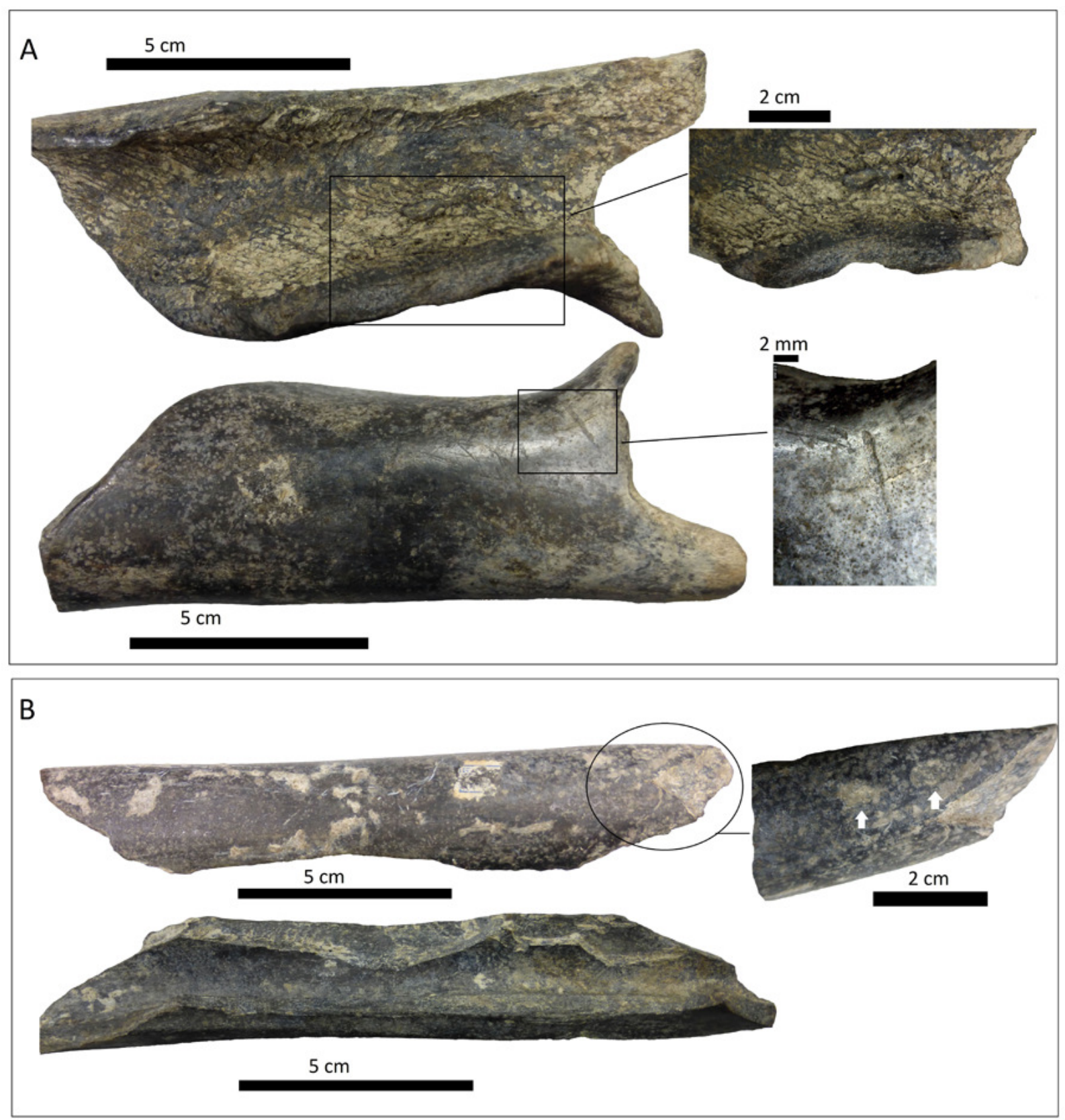

C
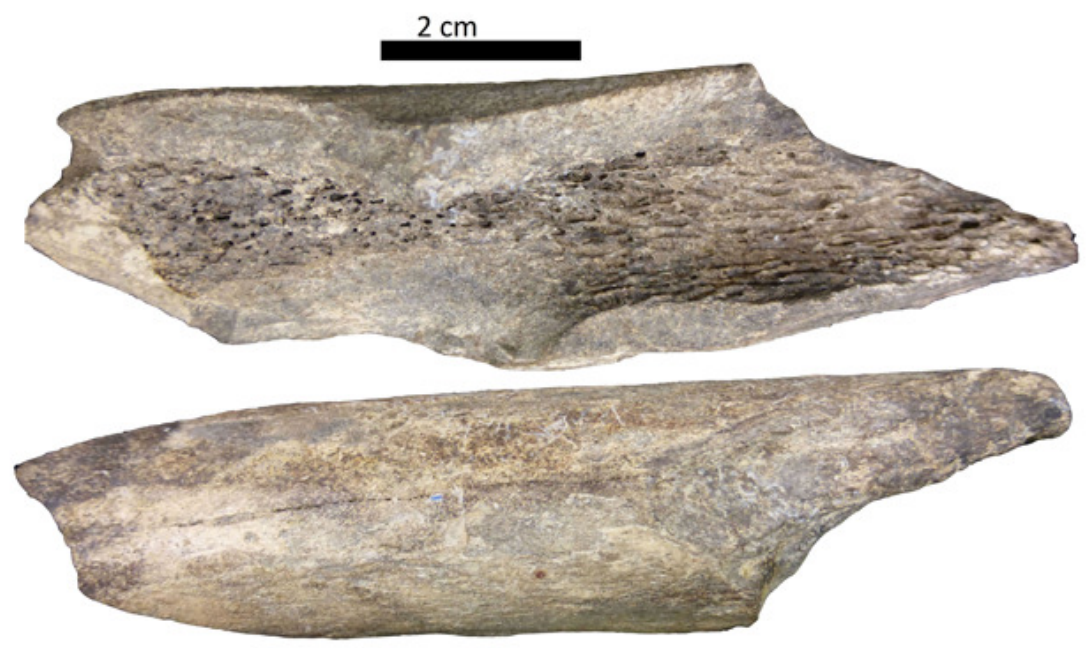

Peer) reviewing PDF | (201 2:CHECK 6 Feb 2017) 


\section{Figure 9}

Figure 9.

Bone shafts showing carnivore intervention from MLP with spiral fracture and magnification of crenulated edge: A) MLP 15-I-20-37; B) MLP 15-I-20-38 

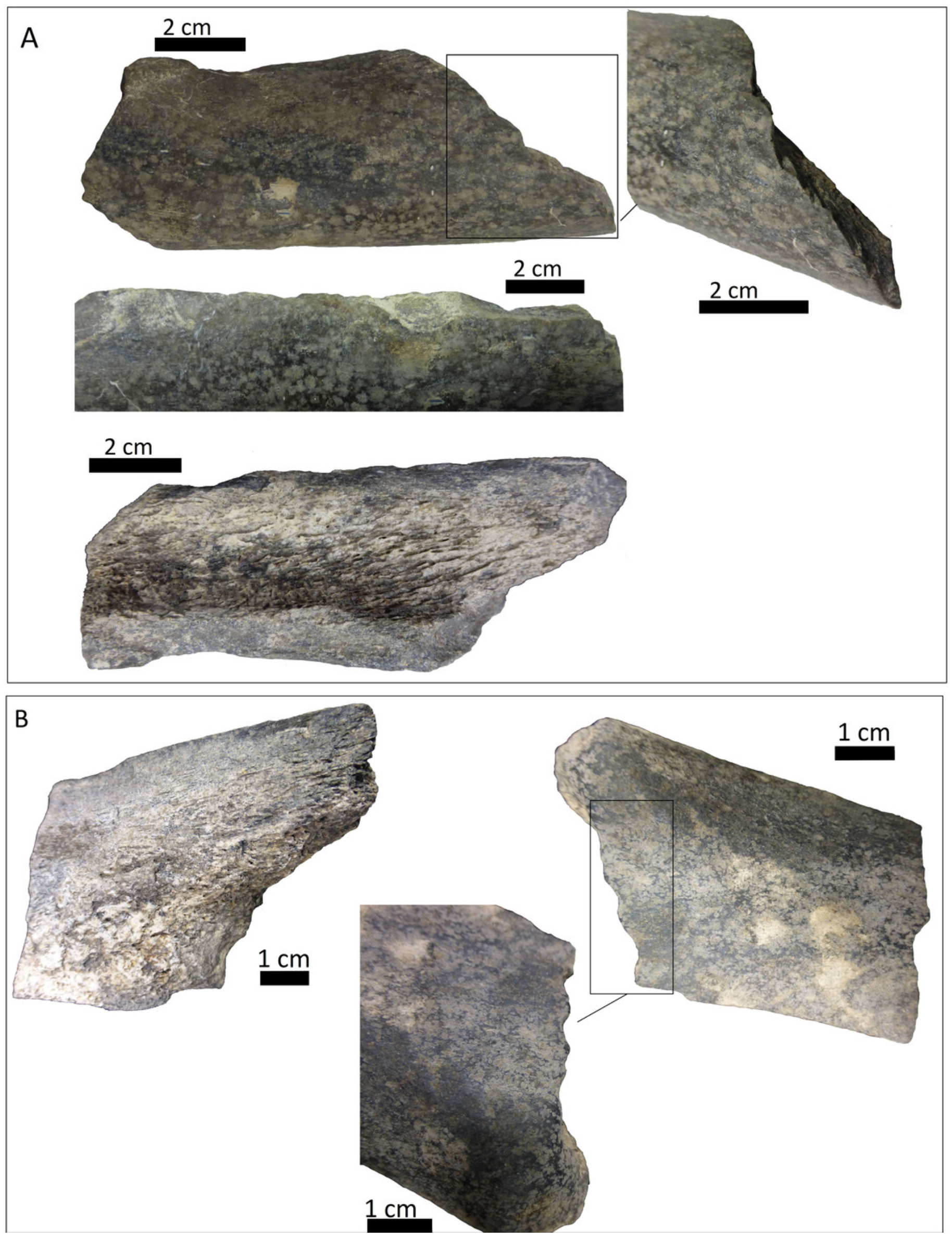


\section{Figure 10}

Figure 10.

Indeterminate fragment of bone with puncture and amplification of the puncture with DinoLite measurements: A) MLP 15-I-20-36; B) MLP 15-I-20-39.
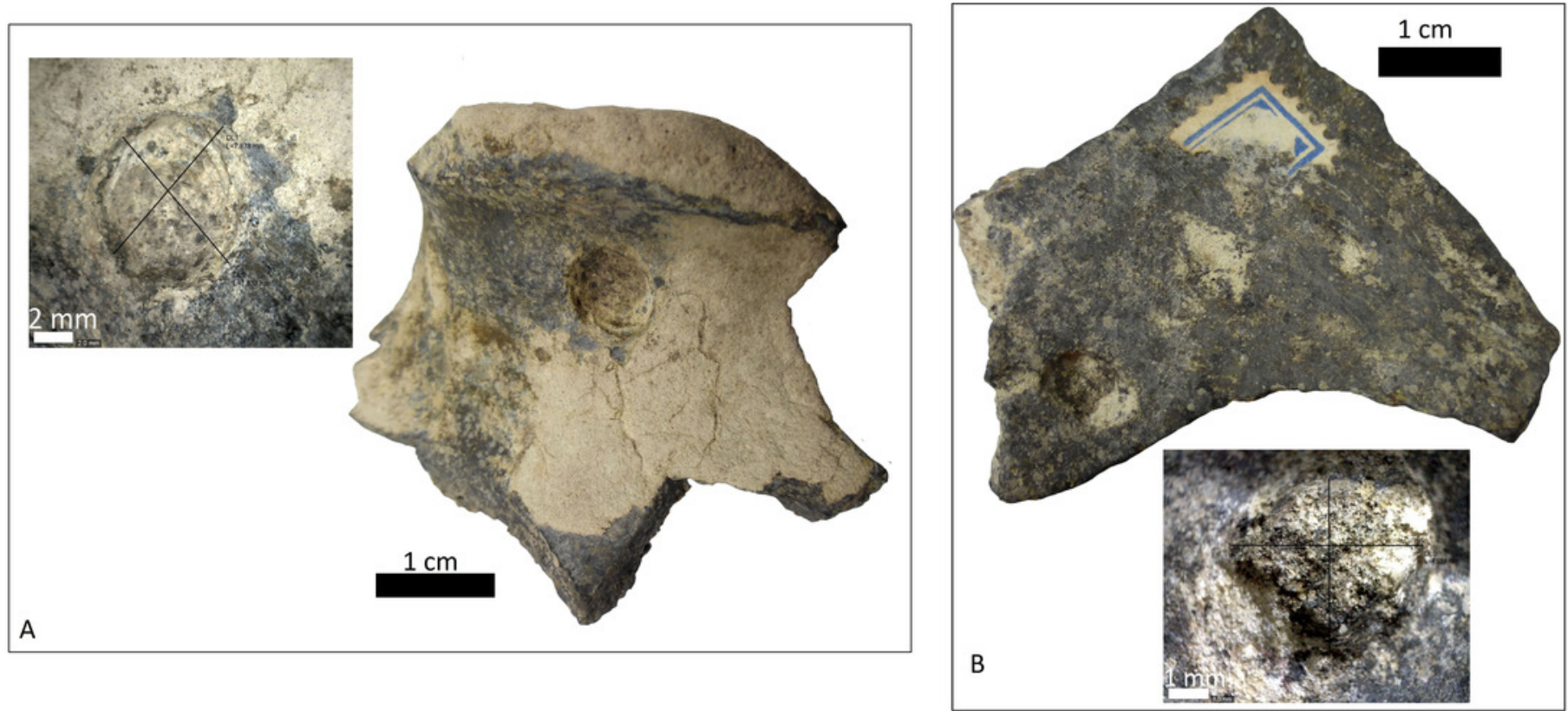